\title{
Ecological risk assessments of endocrine disrupting organotin compounds using marine neogastropods in Hong Kong
}

\author{
Kenneth M.Y. Leung ${ }^{\text {a,* }}$, Rita P.Y. Kwong ${ }^{\text {a }}$, W.C. Ng ${ }^{a}$, Toshihiro Horiguchi ${ }^{b}$, J.W. Qiu ${ }^{c}$, \\ Ruiqiang Yang ${ }^{\mathrm{d}}$, Maoyong Song ${ }^{\mathrm{d}}$, Guibin Jiang ${ }^{\mathrm{d}}$, Gene J. Zheng ${ }^{\mathrm{e}}$, Paul K.S. Lam ${ }^{\mathrm{e}}$ \\ ${ }^{a}$ The Swire Institute of Marine Science, Department of Ecology \& Biodiversity, The University of Hong Kong, Pokfulam, Hong Kong, PR China \\ ${ }^{\mathrm{b}}$ National Institute for Environmental Studies, 16-2, Onogawa, Tsukuba, Ibaraki 305-8506, Japan \\ ${ }^{\mathrm{c}}$ Department of Biology, Hong Kong Baptist University, Kowloon, Hong Kong, PR China \\ ${ }^{\mathrm{d}}$ State Key Laboratory of Environmental Chemistry and Ecotoxicology, Research Center for Eco-Environmental Sciences, \\ Chinese Academy of Sciences, P.O. Box 2871, Beijing 100085, PR China \\ ${ }^{\mathrm{e}}$ Centre for Coastal Pollution and Conservation, Department of Biology and Chemistry, City University of Hong Kong, Hong Kong, PR China
}

Received 24 November 2005; received in revised form 9 March 2006; accepted 21 March 2006

Available online 3 May 2006

\begin{abstract}
As active ingredients of anti-fouling paints that are widely used on ship hulls, organotin compounds, in particular tributyltin (TBT), are well-known endocrine disruptors causing sex changes in marine organisms and widespread in coastal waters and sediments worldwide. In this study, a comprehensive ecological risk assessment (ERA) of organotins was conducted in Hong Kong waters through determining the imposex status, sex ratio and tissue burdens of these compounds in the neogastropods, Thais clavigera and Thais luteostoma collected from 29 coastal sites. We also investigated the historical trend of organotin effects on these gastropods, and performed a probabilistic ERA based on tissue burden of TBT in the animals. Our results demonstrated that imposex indices were positively correlated with the body burden of organotins in the gastropods. Across all sites, the sex ratio (female:male) decreased significantly with increasing imposex levels or tissue burden of organotins, implying that such pollutants can result in a male-biased population, potentially leading to local extinction in extreme cases. Based on the ERA, 5.4\% of all populations of $T$. clavigera are at risk due to exposure to TBT; the risks include growth inhibition, impairment of immune functions and reduced fitness. Seriously impacted areas included Aberdeen, Repulse Bay, Butterfly Beach, Mui Wo and Ha Mei Wan. A comparison with historical data revealed that there had been some improvement in the areas with low marine traffic, and distant from the major harbour/port. This could partly be due to the restriction on the use of TBT on small vessels ( $<25 \mathrm{~m}$ in length) since 1992. Nevertheless, the organotin contamination still remains severe in areas with high marine traffic or adjacent to large harbours/ports. In particular, the situation in the northeastern waters of Hong Kong has been getting worst since 1996 that is probably associated with the rapid development of the cargo container port at Yantian in China.
\end{abstract}

(C) 2006 Elsevier Ltd. All rights reserved.

Keywords: International Maritime Organization; Biomarkers; Antifoulant; Rockshell

\section{Introduction}

Organotin compounds (OTs) such as tributyltin (TBT) and triphenyltin (TPT) have been adopted in industrial applications since their biocidal properties were revealed in early 1950s (Bennett, 1996). They are used for various

\footnotetext{
* Corresponding author. Tel.: +852 2299 0607; fax: +852 25176082.

E-mail address: kmyleung@hkucc.hku.hk (K.M.Y. Leung).
}

purposes such as molluscicides and disinfectants, but most importantly, OTs are applied globally as wood preservatives and anti-fouling paints (de More, 1996). The toxic effects of OTs, particularly TBT on non-target organisms, have been reported since late 1970s in various marine taxa (e.g. Alzieu, 1996); among them, gastropods and bivalve molluscs are of higher concern due to the induction of toxic effects at low concentrations (Gibbs et al., 1987; Leung et al., 2001). In marine neogastropods, TBT causes 
imposex which refers to the development of vas deferens and formation of penis in female snails (Gibbs et al., 1987). The symptoms were first reported in early 1970s (Blaber, 1970; Smith, 1971), while its linkage with TBT was established a decade later (Smith, 1981a,b). This relationship meant that monitoring of TBT pollution can be effectively carried out based on the degree of imposex development in neogastropods in the receiving environment. Indeed, imposex in the female can occur at TBT concentration as low as $1 \mathrm{ng} \mathrm{l}^{-1}$ (Gibbs et al., 1988). The degree of imposex can be gauged by two main indices, namely relative penis size index (RPSI) and vas deferens stage index (VDSI) (Gibbs et al., 1988). In general, there is a strong positive correlation between the imposex indices and ambient TBT level or distance from harbour/dockyard (Bryan et al., 1987; Gibbs et al., 1988; Horiguchi et al., 1994, 1997; Chiavarini et al., 2003).

Imposex has been reported in approximately 150 gastropod species (Matthiessen et al., 1999). The resultant impact of such dysfunctions in the reproductive system of female snails, however, varies amongst species (Matthiessen and Gibbs, 1998). For some species, such as Nassarius reticulates and Ilyanassa obsolata, the reproductive activity of the imposex females appeared not to be affected, while in other species, such as Nucella lapillus and Thais clavigera (Gibbs and Bryan, 1986; Horiguchi et al., 1994), the developing vas deferens may block the oviduct opening (vulva), resulting in the sterilization of the females due to the failure in egg capsule release (Bryan et al., 1986). Previously, there were various proposed mechanisms of this endocrine disruption (Matthiessen and Gibbs, 1998), including the aromatase inhibition hypothesis (Spooner et al., 1991; Bettin et al., 1996; Santos et al., 2005), testosterone excretion-inhibition hypothesis (Ronis and Mason, 1996), neuroendocrine system disruption hypothesis (Féral and LeGall, 1983 ) and the APGWamide hypothesis (Oberdörster and McClellan-Green, 2000, 2002). Among them, the aromatase inhibition hypothesis tended to receive more attention (Spooner et al., 1991; Bettin et al., 1996; Oehlmann et al., 1996a). In this hypothesis, it is proposed that TBT inhibits the action of cytochrome P450-dependent aromatase, which is involved in the conversion of testosterone to $17 \beta$-estradiol, and such an interruption results in a buildup of testosterone in the female to induce the male characters. However, Nishikawa et al. (2004) recently demonstrated that direct binding of TBT or TPT onto the retinoid X receptor (RXR) could induce imposex in females of T. clavigera. The RXR is known to be a key factor involved in the mediation of several hormone response systems in mammals. Despite more work being required to fully understand the mechanism of TBT-induced imposex, this pioneering study sheds new light on the importance of molecular controls for the hormonal systems in the gastropod.

With the better understanding of the harmful effects of OTs to marine organisms, banning of TBT-based antifoulant application on boats shorter than $25 \mathrm{~m}$ in length has been enforced in several countries including France (1982), United Kingdom (1987), USA (1988), Australia (1989), Japan (1990) and European Union (1991) (Evans et al., 1995; Gibson and Wilson, 2003). In Hong Kong, a similar restriction on the use of TBT paint was enforced in 1992. Action at a global scale was also initiated as the pollution problem was recognized internationally. In October 2001, the International Maritime Organization (IMO) adopted the International Convention on the Control of Harmful Anti-Fouling Systems on Ships (CHAFSS), which called for a global prohibition on the application of OT compounds to act as biocides in anti-fouling systems on ships by 1 January 2003, and a complete prohibition by 1 January 2008. The date for the convention to enter into force has, however, not be finalized pending the minimum number of ratified states ( 25 required, but only 11 had agreed by June 2005), and percentage tonnage $(25 \%$ required, but only $9.28 \%$ signed by June 2005) (IMO, 2005).

Hong Kong is a well-known international port, with the world's largest container throughput (Marine Department of Hong Kong SAR, 2005) and continuously increasing vessel activity (Appendix 1) within a sea boundary of about $1600 \mathrm{~km}^{2}$. Sea traffic is most intense around the Victoria Harbour, located between the Hong Kong Island and Kowloon Peninsula, where the sea is packed with container loading/unloading facilities and associated shipping channels, dockyards, public piers, typhoon shelters, mooring buoys, etc. Away from the harbour, the water is also utilized as shipping channels, piers, typhoon shelters, fishing grounds and mariculture zones. These activities/facilities are believed to release considerate amounts of OTs to the local marine environment. Additional vessel-based pollutants also come from across the border. For example, Yantian Port (Shenzhen) (Fig. 1.) is located less than $5 \mathrm{~km}$ from the boundary of Hong Kong and started its operation in 1996. With rapid investment and development, the port is now the sixth busiest container port in the world. OTs is undoubtedly an important contaminant in Hong Kong waters, and the problem is expected to be exacerbated due to the rapid development of logistic industry in local and peripheral areas, as well as the delayed ratification of the IMO International Convention of the CHAFSS.

Previous studies on the extent and trend of the OT contamination in Hong Kong are, however, limited to hydrological, chemical and biological aspects. TBT contamination in Hong Kong was first reported in 1991 (Lau, 1991). High concentrations of TBT were detected during 1988 in water and sediment samples from marinas, typhoon shelter and mariculture sites, up to $1000 \mathrm{ng} / 1$ (water) and $1160 \mathrm{ng} / \mathrm{g}$ (sediment) in selected sites, while the body burden of TBT as high as $672 \mathrm{ng} / \mathrm{g}$ dry wt was also detected in clams (species not specified) (Lau, 1991). The problem persisted between 1988 and 1994, as reflected by sediment analysis (Ko et al., 1995). Imposex in neogastropods, as possession of a rudimentary penis in female, was first described in T. clavigera in 1988 (Tong, 1988). 


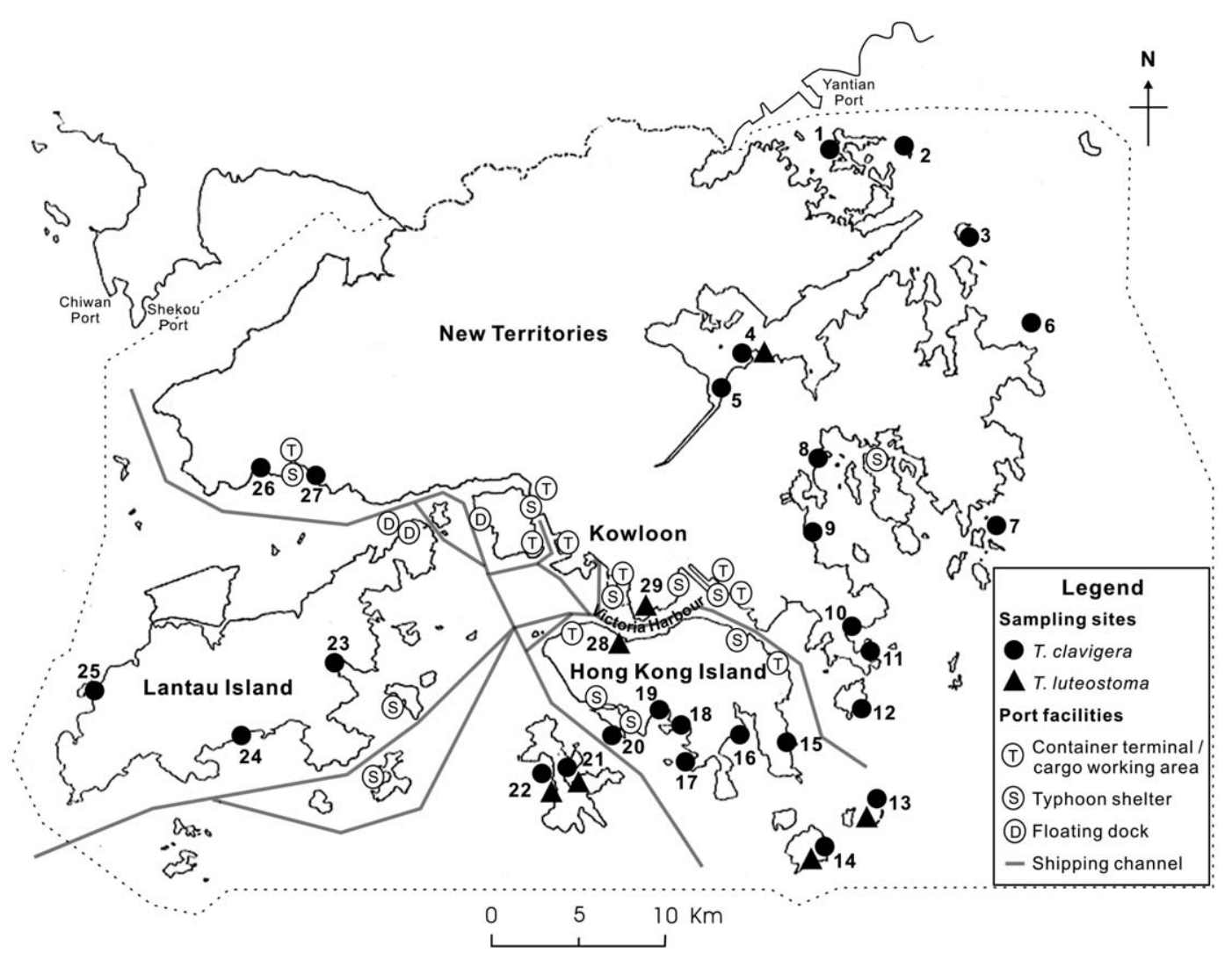

Fig. 1. Map of Hong Kong showing the sampling sites for Thais clavigera and Thais luteostoma, locations of major shipping activities and facilities. The name of each numbered site is shown in Table 2. Dotted line represents the boundary of Hong Kong waters.

Mak (1992) studied imposex in T. clavigera in 1990 and recorded a $100 \%$ imposex rate for female samples from 11 locations in Hong Kong. After the partial restricted use of TBT in 1992, a few more studies on the imposex of Thais spp. have been conducted in 1996 (Blackmore, 2000) and 1997 (Li, 2003) without measuring the tissue burdens of OTs. Although both studies only visited a limited number of sites (6 and 17 sites, respectively), their results generally suggested high levels of TBT contamination throughout Hong Kong waters.

This study primarily aims to provide a comprehensive ecological risk assessment (ERA) of OTs, in particular TBT in Hong Kong waters through (1) determining the imposex status, sex ratio and tissue burdens of these compounds in the neogastropods, T. clavigera and T. luteostoma collected from 29 coastal sites and (2) performing a probabilistic ERA based on tissue burden of TBT in these animals. With a wider coverage of the territorial waters of Hong Kong, a more precise spatial pattern is generated. In combination of the related studies in the last 15 years, a temporal trend of the OT contamination is revealed. Relationships between body burden of OTs and imposex index or sex ratio are also established for these biomonitors. The results will provide an essential 'baseline' reference for the long-term monitoring programme in Hong Kong, and provide a methodological framework for ERA of OTs in Southeast Asia.

\section{Materials and methods}

\subsection{Sample collection}

Sampling of the two target species was conducted during June to July 2004 . Adult $T$. clavigera $(22.2-36.0 \mathrm{~mm}$ shell length) and $T$. luteostoma (31.8-43.1 $\mathrm{mm}$ shell length) were collected from 27 and 7 intertidal shores along the coastline of Hong Kong, respectively (Fig. 1). Both species occurred at five of the sampling sites, making up a total of 29 unique sites. The collection sites were selected to cover areas with various degree of organotin pollution. Number of collected specimen for each site ranged from 30 to 40 individuals, giving a total sample size of 1060 individuals for $T$. clavigera and 270 for T. luteostoma (Table 1).

\subsection{Imposex identification}

In the laboratory, shell length for each specimen was measured to the nearest $0.1 \mathrm{~mm}$ using vernier callipers. The shell was crushed in a vice, the soft body was removed, examined and measured under a binocular microscope. Sex of each specimen was determined by identification of the sperm ingesting gland and the capsule gland in females and the presence of the prostate gland in males (Horiguchi et al., 1994; Blackmore, 2000). Penis length was measured to the nearest $0.1 \mathrm{~mm}$ for males and females which were 
Table 1

Site name, number of animals, shell length, percentage of imposex females, penis length in female, relative penis size index (RPSI), vas deferens sequence index (VDSI) and percentage of sterilized females for Thais clavigera and Thais luteostoma, respectively in this study

\begin{tabular}{|c|c|c|c|c|c|c|c|c|c|c|c|c|}
\hline \multirow[t]{3}{*}{ No. } & \multirow[t]{3}{*}{ Site } & \multirow[t]{3}{*}{$n(\mathrm{~m}: \mathrm{f})$} & \multirow[t]{3}{*}{$\%$ female } & \multirow{3}{*}{$\begin{array}{l}\text { Male } \\
\text { Shell length } \\
(\mathrm{mm}) \\
\text { Mean } \pm \mathrm{SD}\end{array}$} & \multicolumn{7}{|l|}{ Female } & \multirow{3}{*}{$\begin{array}{l}\text { Distance from } \\
\text { shipping } \\
\text { activity }(\mathrm{km})\end{array}$} \\
\hline & & & & & \multirow{2}{*}{$\begin{array}{l}\text { Shell length } \\
(\mathrm{mm}) \\
\text { Mean } \pm \mathrm{SD}\end{array}$} & \multirow[t]{2}{*}{$\%$ imposex } & \multirow{2}{*}{$\begin{array}{l}\text { Penis length } \\
(\mathrm{mm}) \\
\text { Mean } \pm \mathrm{SD}\end{array}$} & \multirow[t]{2}{*}{ RPSI } & \multicolumn{2}{|l|}{ VDSI } & \multirow[t]{2}{*}{$\begin{array}{l}\% \text { sterile } \\
\text { female }\end{array}$} & \\
\hline & & & & & & & & & median & mean & & \\
\hline \multicolumn{13}{|c|}{ T. clavigera } \\
\hline 1 & Kat $\mathrm{O}$ & $40(15: 25)$ & 62.5 & $29.8 \pm 2.0$ & $30.6 \pm 3.0$ & 100 & $3.43 \pm 1.24$ & 1.59 & 4.0 & 3.92 & 0.0 & 23.8 \\
\hline 2 & Pak Sha Chau & $40(19: 21)$ & 52.5 & $31.6 \pm 2.9$ & $33.6 \pm 4.4$ & 100 & $2.30 \pm 0.66$ & 0.37 & 4.0 & 3.57 & 0.0 & 19.5 \\
\hline 3 & Chek Chau & $40(12: 28)$ & 70.0 & $30.1 \pm 3.0$ & $29.2 \pm 2.0$ & 100 & $2.30 \pm 0.71$ & 0.57 & 3.5 & 3.50 & 0.0 & 17.7 \\
\hline 4 & Wu Kwai Sha & $40(19: 21)$ & 52.5 & $31.0 \pm 2.5$ & $28.7 \pm 2.6$ & 100 & $1.72 \pm 0.64$ & 0.17 & 3.0 & 2.67 & 0.0 & 24.0 \\
\hline 5 & Heng On Estate & $40(18: 22)$ & 55.0 & $36.0 \pm 3.3$ & $34.8 \pm 3.1$ & 100 & $3.85 \pm 1.10$ & 0.84 & 4.0 & 3.64 & 0.0 & 27.0 \\
\hline 6 & Wong Mau Chau & $40(10: 30)$ & 75.0 & $31.1 \pm 2.0$ & $32.2 \pm 2.5$ & 100 & $1.68 \pm 0.50$ & 0.11 & 3.0 & 3.03 & 0.0 & 21.0 \\
\hline 7 & Kong Tau Pai & $40(11: 29)$ & 72.5 & $28.8 \pm 2.3$ & $29.8 \pm 3.0$ & 100 & $2.30 \pm 0.71$ & 0.06 & 2.0 & 2.38 & 0.0 & 15.3 \\
\hline 8 & Sai Kung Pier & $30(20: 10)$ & 33.3 & $29.0 \pm 3.8$ & $33.4 \pm 2.6$ & 100 & $8.75 \pm 1.22$ & 34.38 & 4.0 & 4.70 & 40.0 & 0.0 \\
\hline 9 & UST & $40(22: 18)$ & 45.0 & $33.7 \pm 2.7$ & $34.6 \pm 3.0$ & 100 & $7.42 \pm 1.82$ & 8.85 & 4.0 & 4.17 & 11.1 & 3.0 \\
\hline 10 & Clear Water Bay & $40(12: 28)$ & 70.0 & $30.4 \pm 2.6$ & $32.3 \pm 3.4$ & 100 & $1.95 \pm 0.65$ & 0.53 & 3.0 & 3.04 & 0.0 & 13.0 \\
\hline 11 & Shek Mei Tao & $30(7: 23)$ & 76.6 & $22.2 \pm 1.7$ & $23.8 \pm 2.4$ & 100 & $1.14 \pm 0.26$ & 0.15 & 3.0 & 3.22 & 0.0 & 6.7 \\
\hline 12 & Tung Lung Island & $40(17: 23)$ & 57.5 & $31.4 \pm 2.1$ & $30.9 \pm 2.7$ & 100 & $5.98 \pm 1.20$ & 12.59 & 4.0 & 4.00 & 0.0 & 6.0 \\
\hline 13 & Waglan Island & $40(14: 26)$ & 65.0 & $32.1 \pm 3.9$ & $35.4 \pm 5.6$ & 100 & $1.78 \pm 0.56$ & 0.18 & 3.0 & 3.00 & 0.0 & 12.6 \\
\hline 14 & Po Toi & $40(15: 25)$ & 62.5 & $29.6 \pm 2.1$ & $30.0 \pm 2.5$ & 100 & $2.89 \pm 0.99$ & 2.32 & 4.0 & 3.52 & 0.0 & 13.6 \\
\hline 15 & Shek O & $40(20: 20)$ & 50.0 & $30.8 \pm 1.9$ & $31.5 \pm 2.0$ & 100 & $6.73 \pm 1.24$ & 29.65 & 4.0 & 3.90 & 5.0 & 6.0 \\
\hline 16 & Turtle Cove & $40(16: 24)$ & 60.0 & $31.9 \pm 2.0$ & $33.5 \pm 2.6$ & 100 & $2.45 \pm 0.80$ & 0.43 & 3.0 & 3.33 & 0.0 & 13.7 \\
\hline 17 & Chung Hum Kok & $40(19: 21)$ & 52.5 & $31.9 \pm 1.7$ & $32.6 \pm 1.8$ & 100 & $4.74 \pm 1.38$ & 9.01 & 4.0 & 4.10 & 4.8 & 7.0 \\
\hline 18 & Repulse Bay & $40(21: 19)$ & 42.5 & $31.7 \pm 2.5$ & $32.5 \pm 3.3$ & 100 & $5.87 \pm 1.67$ & 11.84 & 4.0 & 3.90 & 10.5 & 7.5 \\
\hline 19 & Deep Water Bay & $40(23: 17)$ & 47.5 & $30.9 \pm 1.6$ & $30.8 \pm 1.7$ & 100 & $4.95 \pm 1.70$ & 7.72 & 4.0 & 4.35 & 29.4 & 6.9 \\
\hline 20 & Aberdeen & $40(34: 6)$ & 15.0 & $29.9 \pm 3.0$ & $30.2 \pm 2.6$ & 100 & $8.45 \pm 1.68$ & 64.22 & 5.0 & 5.00 & 83.3 & 0.0 \\
\hline 21 & Sok Kwu Wan & $40(26: 14)$ & 35.0 & $32.7 \pm 1.9$ & $33.3 \pm 3.2$ & 100 & $7.32 \pm 1.51$ & 12.07 & 6.0 & 5.36 & 71.4 & 0.0 \\
\hline 22 & Ha Mei Wan & $40(17: 23)$ & 57.5 & $29.2 \pm 2.5$ & $29.6 \pm 2.6$ & 100 & $3.71 \pm 0.89$ & 1.89 & 4.0 & 3.65 & 0.0 & 3.3 \\
\hline 23 & Mui Wo & $40(17: 23)$ & 57.5 & $31.8 \pm 2.6$ & $31.3 \pm 2.4$ & 100 & $5.06 \pm 2.36$ & 3.05 & 4.0 & 4.00 & 0.0 & 0.0 \\
\hline 24 & Cheung sha & $40(15: 25)$ & 62.5 & $29.9 \pm 1.7$ & $30.6 \pm 2.1$ & 100 & $3.38 \pm 1.45$ & 1.26 & 4.0 & 4.00 & 0.0 & 14.0 \\
\hline 25 & Tai $\mathrm{O}$ & $40(21: 19)$ & 47.5 & $24.6 \pm 2.4$ & $26.6 \pm 2.9$ & 100 & $3.31 \pm 1.31$ & 3.18 & 4.0 & 3.79 & 0.0 & 13.4 \\
\hline 26 & Butterfly Beach & $40(31: 9)$ & 22.5 & $30.0 \pm 3.0$ & $28.3 \pm 1.8$ & 100 & $6.57 \pm 1.85$ & 15.56 & 4.0 & 4.11 & 33.3 & 1.4 \\
\hline \multirow[t]{2}{*}{27} & Kadoorie Beach & $40(25: 15)$ & 37.5 & $29.1 \pm 1.4$ & $29.3 \pm 1.8$ & 100 & $9.05 \pm 1.48$ & 38.43 & 5.0 & 4.87 & 53.3 & 1.6 \\
\hline & Total & 1060 & & & & & & & & & & \\
\hline \multicolumn{13}{|c|}{ Thais luteostoma } \\
\hline 4 & Wu Kwai Sha & $40(18: 22)$ & 55.0 & $39.7 \pm 3.3$ & $41.4 \pm 3.5$ & 100 & $2.71 \pm 0.84$ & 0.17 & 3.0 & 2.96 & 0.0 & 24.0 \\
\hline 13 & Waglan Island & $30(16: 24)$ & 60.0 & $31.9 \pm 2.9$ & $33.2 \pm 3.7$ & 100 & $1.49 \pm 0.66$ & 0.93 & 3.0 & 3.11 & 0.0 & 13.6 \\
\hline 14 & Po Toi & $40(11: 19)$ & 63.0 & $32.7 \pm 4.5$ & $35.8 \pm 5.4$ & 100 & $3.04 \pm 2.27$ & 0.19 & 3.0 & 2.92 & 0.0 & 12.6 \\
\hline 21 & Sok Kwu Wan & $40(18: 22)$ & 55.0 & $40.7 \pm 3.4$ & $41.0 \pm 3.4$ & 100 & $6.66 \pm 2.49$ & 4.37 & 5.0 & 4.82 & 54.5 & 0.0 \\
\hline 22 & Ha Mei Wan & $40(13: 27)$ & 66.0 & $31.8 \pm 3.4$ & $32.9 \pm 4.5$ & 100 & $4.09 \pm 4.42$ & 2.01 & 3.0 & 3.33 & 0.0 & 3.3 \\
\hline 28 & Central Pier & $40(27: 13)$ & 33.0 & $36.8 \pm 4.1$ & $37.1 \pm 4.0$ & 100 & $9.71 \pm 2.20$ & 14.13 & 5.0 & 4.92 & 76.9 & 0.0 \\
\hline \multirow[t]{2}{*}{29} & Tsim Sha Tsui & $40(14: 26)$ & 65.0 & $43.1 \pm 5.1$ & $41.0 \pm 3.7$ & 100 & $12.88 \pm 1.78$ & 23.44 & 5.0 & 5.31 & 84.6 & 0.0 \\
\hline & Total & 270 & & & & & & & & & & \\
\hline
\end{tabular}

not narcotized. The degree of the imposex was estimated using the relative penis size index (RPSI) and vas deferens sequence index (VDSI) (Gibbs et al., 1987; Horiguchi et al., 1994). The RPSI was calculated as

$$
\begin{aligned}
\text { RPSI }= & (\text { mean length of female penis })^{3} \\
& /(\text { mean length of male penis })^{3} \times 100
\end{aligned}
$$

The VDSI, which was firstly developed by Gibbs et al. (1987) for the dogwhelk Nucella lapillus and later adopted for other neogastropod species like $T$. clavigera (Blackmore, 2000), has seven stages (0-6), with stage 0 indicating no effect. At stage 1, the proximal section of the vas deferens had developed; at stage 2, a penis had formed and the vas deferens had increased in length; at stage 3 , a vas deferens had developed posterior to the penis, and the posterior vas deferens outgrowth had developed further. At stage 4 , the two outgrowths had fused into a continuous vas deferens. At stages 5 and 6 , the females were sterile; at stage 5 , the outgrowth had blocked the genital papilla while aborted capsules were seen in the capsule gland at stage 6 (Gibbs et al., 1987; Blackmore, 2000). Recent microscopic observation for the development of the vas deferens and penis in imposex-exhibiting females of $T$. clavigera revealed 
that the VDSI of $T$. clavigera was only a little different from that of $N$. lapillus (Horiguchi et al., unpublished data). Mean VDSI was computed for each site. To maintain consistency, the imposex identification was conducted by the same person (i.e. R.P.Y. Kwong) throughout the study. Randomly selected samples (46 T. clavigera and 13 $T$. luteostoma) were re-examined by $\mathrm{T}$. Horiguchi for crosschecking the VDSI. Agreement of the identification was subsequently tested using a paired $t$-test. The historical trend of imposex levels in these gastropods, between 1990 and 2004, was also compared based on the data reported in Mak (1992), Blackmore (2000), Li (2003) and the present study.

\subsection{Organotin analysis}

The concentrations of organotin species, monobutyltin (MBT), dibutyltin (DBT) and tributyltin (TBT), were quantified in the whole soft-body tissues of pooled animals. Two replicates of ten pooled animals were analysed for each study site. These organotin compounds were extracted using the method described in Sudaryanto et al. (2002) and Kan-Atireklap et al. (1997). The analytical procedures followed those described in Szpunar et al. (1996). To avoid the possibility of bias, samples were coded so that the analysts did not know the collection locations of the samples prior to analysis. Briefly, about $2 \mathrm{~g}$ (wet wt) of snail tissue sample was homogenized with $70 \mathrm{ml}$ of $0.1 \%$ tropolone/acetone and $5 \mathrm{ml}$ of $2 \mathrm{~N}$ $\mathrm{HCl}$. After centrifugation, the supernatant was transferred to $100 \mathrm{ml}$ of $0.1 \%$ tropolone/benzene, and moisture in the extract was removed with anhydrous sodium sulphate. After concentrating the extract using a rotary evaporator, all BTs in the extract were propylated by adding $10 \mathrm{ml}$ of $n$-propyl magnesium bromide $(\sim 1 \mathrm{~mol} / 1$ in tetrahydrofuran, Kanto Chemical, Tokyo, Japan) as Grignard reagent. Excess reagent was destroyed with $1 \mathrm{~N}$ sulphuric acid, and the propylated mixture was transferred to $10 \%$ benzene/hexane. The solution was purified on a florisilpacked glass column and eluted with hexane. The final hexane solution was concentrated and subjected to analysis by a Gas-Chromatograph (Hewlett-Packard 5890 Series II, CA, USA) equipped with Flame Photometric Detector (GC-FPD). A fused silica capillary column (30 m length $\times 0.25 \mathrm{~mm}$ i.d. $\times 0.25 \mu \mathrm{m}$ film thickness) coasted with $100 \%$ dimethyl polysiloxane (J\&W Scientific, Folsom, CA, USA) was used in the GC oven for separation. The flame photometer was equipped with a $610 \mathrm{~nm}$ band-pass filter that is selected for tin compounds. Known amounts of monobutyltin trichloride, dibutyltin dichloride and tributyltin chloride $(0.1 \mu \mathrm{g}$ each) were used as the external standard mixture. Trihexyltin $\left(0.16 \mu \mathrm{g} \mathrm{ml}^{-1}\right.$ in acetone) was used as the internal standard. The procedure was validated using the certified reference material (CRM) BCR 477 (mussel tissue). The mean recoveries through the entire analytical procedure for MBT, DBT and TBT were $94.3 \%, 82.2 \%$ and $79.8 \%$, respectively. The detection limit was $0.02-0.05 \mathrm{ng} \mathrm{g}^{-1}$ dry weight $(\mathrm{dw})$. The results are reported as $\mathrm{ng} \mathrm{Sn} \mathrm{g}^{-1} \mathrm{dw}$ where appropriate.

\subsection{Probabilistic ecological risk assessments}

In order to assess the ecological risk of TBT on the Hong Kong populations of $T$. clavigera, a probabilistic risk assessment approach based on tissue burden of TBT was developed for this purpose. The risk can be described using the following equation:

Risk quotient(RQ)

$$
=\frac{\text { Measured tissue concentration }(\text { MTC })}{\text { Predicted no effect tissue concentration(PNETC) }}
$$

If $\mathrm{RQ}<1$, there is low risk to $T$. clavigera population. If $\mathrm{RQ} \geqslant 1$, the population of $T$. clavigera is at certain risk due to TBT. The PNETCs were extracted from peerreviewed literature on the chronic and sub-chronic effects of TBT on gastropod and bivalve molluscs. As most of the studies only measured the predicted no effect concentration (PNEC) of TBT in water, appropriate bioconcentration factors (BCFs) were applied to convert the TBT concentration in water into tissue concentration value, i.e. $\mathrm{PNETC}=\mathrm{PNEC} / \mathrm{BCF}$. The corresponding $\mathrm{BCF}$ values were extracted from relevant peer-reviewed literature (Appendix 4). A geometric mean was used as a PNETC if there were multiple data for the same species. All available PNETC values were plotted as a species sensitivity distribution to serve as an effect distribution (Wheeler et al., 2002). The MTC was the mean tissue concentration of TBT obtained from each site in Hong Kong (Section 2.3). All MTC values were also plotted as a cumulative function to serve as an exposure distribution. A distribution of RQ values was finally computed using Monte Carlo simulation with 10,000 iterations, based on the distributions of MTC and PNETC. The simulation was carried out using@Risk software (version 4.5.2, professional edition, 2002, Palizade Corporation). The probability of $T$. clavigera populations in Hong Kong, being at risk (i.e. $R Q \geqslant 1$ ), was subsequently obtained from the RQ frequency histogram.

\section{Results}

\subsection{Imposex level}

Agreement between two observers (i.e. actual measurement and validation check) in the identification of VDSI was good for $T$. luteostoma (paired $t$-test, $t=2.179$, $p=0.096)$. For $T$. clavigera, there was a significant difference in VDSI assessment between the two observers $(t=2.014, p=0.049)$. Nevertheless, the mean difference was only $-5.3 \%$ between the actual measurement and the validation check, indicating a very slight underestimation 
of VDSI in the actual assessment. Therefore, the precision of the current VDSI assessment was regarded as acceptable.

Sex ratio varied among the sampling sites for $T$. clavigera (ranging from $15 \%$ to $77 \%$ female) and T. luteostoma (33-66\% female) (Table 1). Examination of the RPSI and VDSI showed that imposex occurred in all specimens across all sites for both species. The RPSI ranged from 0.06 to 64.22 for $T$. clavigera, and from 0.17 to 23.44 for T. luteostoma (Table 1). Sites with high RPSI included Aberdeen $(\mathrm{RPSI}=64.22, T$. clavigera $)$, Kadoorie Beach (38.43, T. clavigera), Sai Kung Pier $(34.38, T$. clavigera), Shek O (29.65 T. clavigera), Tsim Sha Tsui (23.44, T. luteostoma), and Central Pier (14.13, T. luteostoma).
The mean VDSI ranged from 2.38 to 5.36 for $T$. clavigera and from 2.92 to 5.31 for T. luteostoma (Table 1). Sites with high VDSI included Sok Kwu Wan (mean $\mathrm{VDSI}=5.36, T$. clavigera $; 4.82$, $T$. luteostoma $)$, Aberdeen (5.00, T. clavigera), Kadoorie Beach $(4.87, T$. clavigera), Tsim Sha Tsui (5.31, T. luteostoma), Central Pier (4.92, T. luteostoma) and Sai Kung Pier (4.70, T. clavigera). The lowest individual VDSI recorded was 1, which occurred only in $T$. clavigera, representing the commencement of vas deferens development. Specimens with VDSI of 1 were identified in four sites, namely Wu Kwai Sha, Wong Mau Chau, Kong Tau Pai and Clear Water Bay; all of them were located at relatively clean eastern waters. Sterile females, represented by VDSI of 5 or 6 , were

Table 2

Site name, mean and SD of organotin concentration ( $\mathrm{ng} \mathrm{Sn}^{-1} \mathrm{dw}$ ) in tissue of Thais clavigera and Thais luteostoma

\begin{tabular}{|c|c|c|c|c|c|c|c|c|c|}
\hline \multirow[t]{2}{*}{ No. } & \multirow[t]{2}{*}{ Site } & \multicolumn{2}{|l|}{ MBT } & \multicolumn{2}{|l|}{ DBT } & \multicolumn{2}{|l|}{ TBT } & \multicolumn{2}{|c|}{ Total OT } \\
\hline & & Mean & SD & Mean & $\mathrm{SD}$ & Mean & SD & Mean & $\mathrm{SD}$ \\
\hline \multicolumn{10}{|c|}{ Thais clavigera } \\
\hline 1 & Kat $\mathrm{O}$ & 30.2 & 7.2 & 32.4 & 2.0 & 9.3 & 2.2 & 72.0 & 11.3 \\
\hline 2 & Pak Sha Chau & 21.1 & 3.2 & 20.3 & 3.6 & 8.5 & 1.4 & 49.8 & 8.2 \\
\hline 3 & Chek Chau & $<\mathrm{d} .1$ & 0.0 & $<$ d.l. & 0.0 & $<$ d.1. & 0.0 & $<$ d.l. & 0.0 \\
\hline 4 & Wu Kwai Sha & 107.6 & 2.4 & $<$ d.1. & 0.0 & 3.8 & 0.4 & 111.4 & 2.8 \\
\hline 5 & Heng On Estate & $<\mathrm{d} .1$ & 0.0 & 16.9 & 4.5 & $<$ d.1. & 0.0 & 16.9 & 4.5 \\
\hline 6 & Wong Mau Chau & 71.8 & 4.3 & 12.2 & 3.6 & 1.8 & 0.2 & 85.8 & 8.0 \\
\hline 7 & Kong Tau Pai & 32.9 & 0.2 & 6.3 & 3.0 & 1.8 & 0.2 & 41.0 & 3.4 \\
\hline 8 & Sai Kung Pier & 44.4 & 1.1 & 55.0 & 4.9 & 14.8 & 0.3 & 114.3 & 6.3 \\
\hline 9 & UST & 16.2 & 0.8 & 18.6 & 4.1 & 5.0 & 0.6 & 39.9 & 5.5 \\
\hline 10 & Clear Water Bay & $<\mathrm{d} .1$ & 0.0 & $<$ d.l. & 0.0 & $<$ d.1. & 0.0 & $<$ d.l. & 0.0 \\
\hline 11 & Shek Mei Tao & 22.5 & 3.0 & 19.9 & 6.1 & $<$ d.1. & 0.0 & 42.4 & 9.1 \\
\hline 12 & Tung Lung Island & 41.2 & 3.5 & 29.0 & 0.4 & 5.8 & 1.4 & 76.0 & 5.3 \\
\hline 13 & Waglan Island & 12.0 & 0.3 & 5.6 & 0.5 & 2.4 & 0.0 & 20.0 & 0.8 \\
\hline 14 & Po Toi & 37.8 & 0.8 & 17.6 & 3.0 & 4.0 & 0.0 & 59.4 & 3.8 \\
\hline 15 & Shek O & $<\mathrm{d} .1$ & 0.0 & $<$ d.l. & 0.0 & 4.3 & 2.5 & 4.3 & 2.5 \\
\hline 16 & Turtle Cove & 27.3 & 4.3 & 6.4 & 1.3 & 6.0 & 0.8 & 39.7 & 6.3 \\
\hline 17 & Chung Hum Kok & 21.3 & 1.9 & 13.2 & 1.8 & 3.2 & 0.3 & 37.7 & 4.1 \\
\hline 18 & Repulse Bay & 336.6 & 3.8 & 33.0 & 1.8 & 9.9 & 0.6 & 379.5 & 6.1 \\
\hline 19 & Deep Water Bay & 28.1 & 1.3 & 33.6 & 2.6 & 13.1 & 3.5 & 74.8 & 7.4 \\
\hline 20 & Aberdeen & 700.7 & 35.2 & 197.3 & 29.3 & 16.7 & 0.3 & 914.7 & 64.7 \\
\hline 21 & Sok Kwu Wan & 38.8 & 5.9 & 49.0 & 9.1 & 12.4 & 0.8 & 100.1 & 15.8 \\
\hline 22 & Ha Mei Wan & 108.4 & 1.5 & 39.4 & 5.9 & 18.3 & 1.8 & 166.2 & 9.3 \\
\hline 23 & Mui Wo & 27.2 & 4.2 & 144.2 & 1.0 & 10.9 & 2.0 & 182.3 & 7.2 \\
\hline 24 & Cheung sha & 14.2 & 0.9 & 35.7 & 1.9 & 5.8 & 0.2 & 55.7 & 3.0 \\
\hline 25 & Tai $\mathrm{O}$ & 21.0 & 0.3 & 56.8 & 4.8 & 15.8 & 2.7 & 93.6 & 7.8 \\
\hline 26 & Butterfly Beach & 42.6 & 5.1 & 131.7 & 2.1 & 18.3 & 4.4 & 192.6 & 11.6 \\
\hline 27 & Kadoorie Beach & 41.1 & 2.2 & 58.5 & 5.4 & 15.4 & 1.7 & 115.0 & 9.3 \\
\hline \multicolumn{10}{|c|}{ Thais luteostoma } \\
\hline 4 & Wu Kwai Sha & 20.1 & 2.6 & 3.8 & 0.3 & 2.7 & 0.3 & 26.6 & 3.1 \\
\hline 13 & Waglan Island & $<\mathrm{d} .1$ & 0.0 & $<$ d.l. & 0.0 & 3.8 & 0.2 & 3.8 & 0.2 \\
\hline 14 & Po Toi & 23.2 & 0.2 & 9.4 & 0.0 & 4.4 & 0.7 & 36.9 & 1.0 \\
\hline 21 & Sok Kwu Wan & 22.9 & 1.4 & 30.1 & 3.8 & 16.5 & 2.0 & 69.5 & 7.2 \\
\hline 22 & Ha Mei Wan & 31.5 & 2.0 & $<$ d.l. & 0.0 & 6.6 & 0.6 & 38.0 & 2.6 \\
\hline 28 & Central Pier & 45.7 & 3.6 & 69.9 & 4.6 & 27.6 & 2.8 & 143.2 & 11.1 \\
\hline 29 & Tsim Sha Tsui & 51.2 & 0.8 & 85.4 & 17.6 & 33.5 & 4.0 & 170.1 & 22.4 \\
\hline
\end{tabular}

MBT: monobutyltin; DBT: dibutyltin; TBT: tributyltin; $<$ d.l.: below detection limit. 
recorded in 10 of the 27 sampling sites for $T$. clavigera and 3 of the 7 sites for T. luteostoma. High percentage sterilization occurred in Aberdeen (83.3\%), Sok Kwu Wan (71.4\%), Kadoorie Beach $(53.3 \%)$ for T. clavigera; and Tsim Sha Tsui $(84.6 \%)$, Central Pier $(76.9 \%)$, Sok Kwu Wan $(54.5 \%)$ for T. luteostoma (Table 1).

\subsection{Body burden of organotin compounds}

The mean concentrations of organotin (OT) compounds (MBT, DBT and TBT) in the soft-body tissue ranged from $<0.05$ (i.e. the detection limit) to $914.7 \mathrm{ng} \mathrm{Sn}^{-1} \mathrm{dw}$ (i.e., $<0.05$ to $1458.1 \mathrm{ng}$ OT $\mathrm{g}^{-1} \mathrm{dw}$ ) for $T$. clavigera and 3.8 to $170.1 \mathrm{ng} \mathrm{Sn} \mathrm{g}^{-1}$ (i.e. $9.4-324.4 \mathrm{ng} \mathrm{g}^{-1}$ ) for T. luteostoma (Table 2). In T. clavigera, the mean tissue concentrations of TBT, DBT and MBT ranged from $<0.05$ to $18.33 \mathrm{ng}$ $\mathrm{Sn} \mathrm{g}^{-1},<0.05$ to $197.31 \mathrm{ng} \mathrm{Sn} \mathrm{g}^{-1}$ and $<0.05$ to $700.66 \mathrm{ng}$ $\mathrm{Sn}^{-1}$, respectively (Table 2). These OT compounds, how-

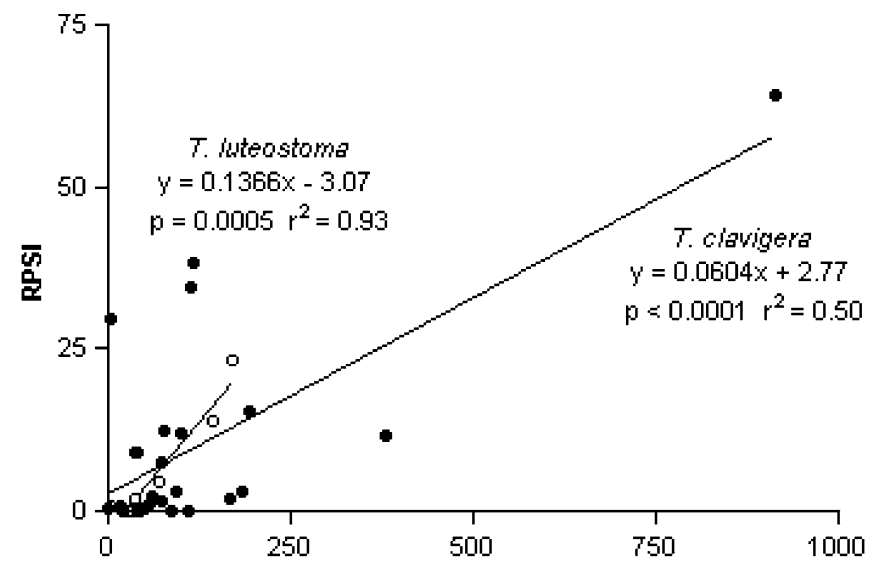

(a) Tissue organotin concentration (ng Sn $\mathrm{g}^{-1} \mathrm{DW}$ )

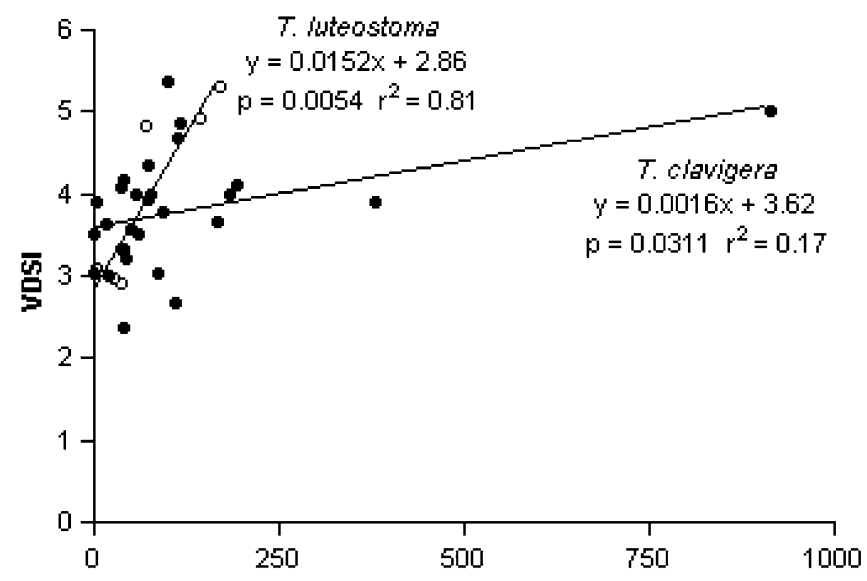

(b) Tissue organotin concentration (ng Sn $\mathrm{g}^{-1} \mathrm{DW}$ )

Fig. 2. Relative penis size index (RPSI; a) and vas deferens sequence index (VDSI; b) versus tissue organotin concentration in Thais clavigera (closed circle) and Thais luteostoma (opened circle). Results of regression analysis are also shown. ever, were not detected in the populations from Chek Chau and Clear Water Bay, although imposex was observed in these two sites. For T. luteostoma, mean tissue TBT ranged from 2.7 to $33.5 \mathrm{ng} \mathrm{Sn}^{-1}$, DBT ranged from $<0.05$ to $85.4 \mathrm{ng} \mathrm{Sn}^{-1}$ and MBT ranged from $<0.05$ to $51.2 \mathrm{ng}$ Sn $\mathrm{g}^{-1}$ (Table 2).
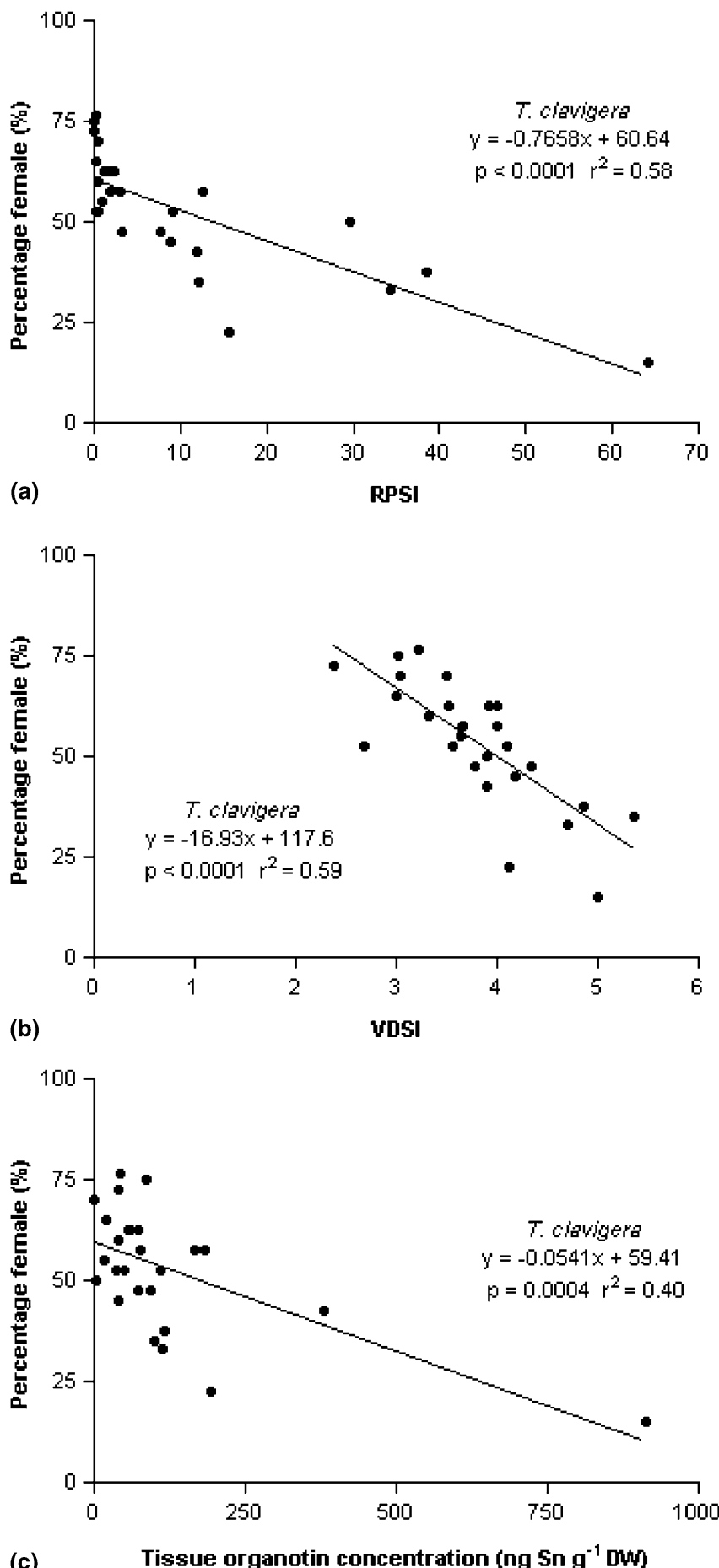

(c)

Fig. 3. Percentage of females versus relative penis size index (RPSI; a) and vas deferens sequence index (VDSI; b) and tissue organotin concentration (c) for Thais clavigera. Results of regression analysis are also presented. 


\subsection{Correlations between imposex level and organotin} burden

Relationships between imposex indices and organotin concentrations were tested using non-parametric Spearman's rank correlation due to the patchiness of part of the dataset. RPSI and VDSI were positively correlated with the tissue concentrations of all three OTs in both $T$. clavigera and $T$. luteostoma (Fig. 2). Similar positive correlations were also identified between TBT and RPSI and VDSI in both species (statistical results shown in Appendix 2). Both imposex indices also increased significantly with increasing DBT concentrations in the tissues of $T$. clavigera but not in T. luteostoma (Appendix 2). Likewise, the percentage of sterilized females (i.e. VDSI $\geqslant 5$ ) also significantly increased with increasing tissue concentration of DBT, TBT or total OTs (Appendix 2). Tissue concentrations of MBT, however, did not show any significant correlation with the imposex indices or percentage of sterilized females in both species.

\subsection{Correlations between sex ratio, imposex level and organotin burden}

Across all sites, the percentage of $T$. clavigera females decreased significantly with increasing RPSI (Regression analysis: $\left.r^{2}=0.58, p<0.0001\right)$, VDSI $\left(r^{2}=0.59, p<\right.$ $0.0001)$ and total tissue concentrations of the three OTs $\left(r^{2}=0.40, p<0.001\right)$ (Fig. 3). Similar relationships were not statistically significant for $T$. luteostoma, probably due to small sample size.
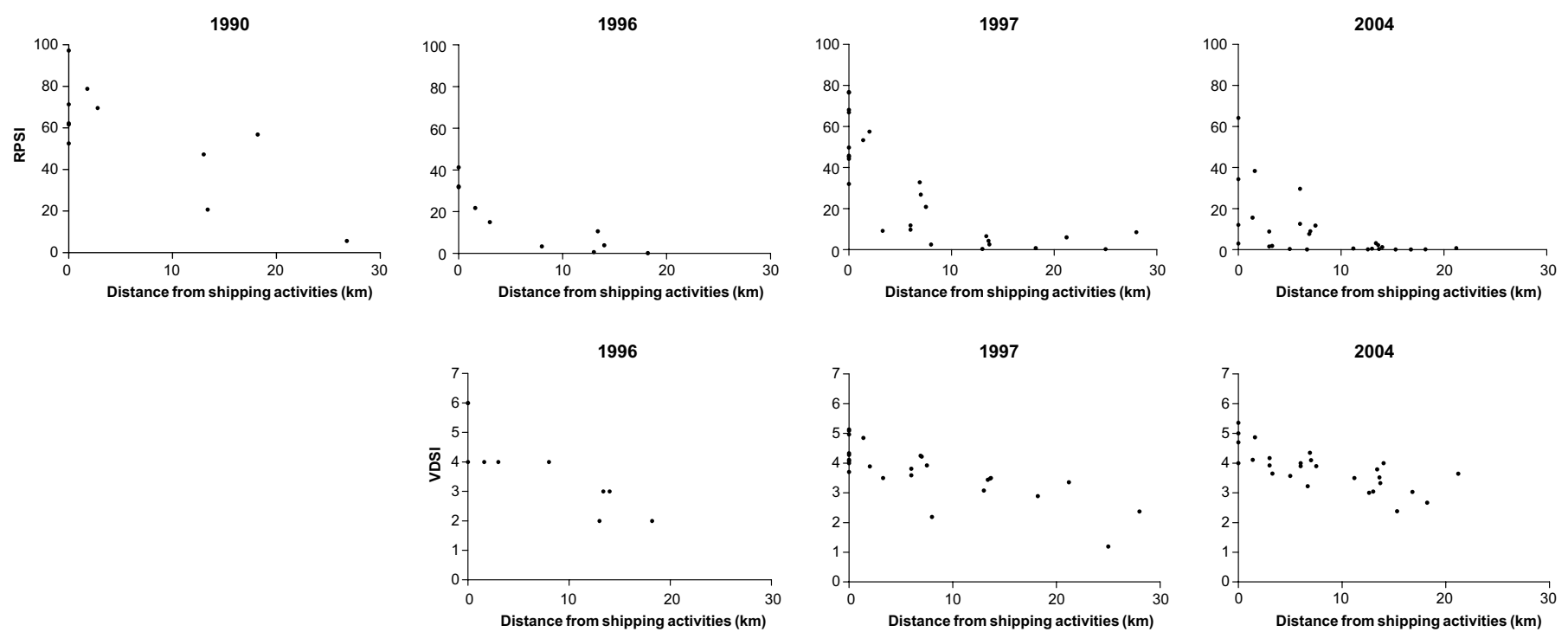

Fig. 4. Relative penis size index (RPSI; upper panel) and vas deferens sequence index (VPSI; lower panel) versus distance from shipping facility/activity for Thais clavigera in 1990, 1996, 1997 and 2004. Data of 1990 are from Mak (1990), 1996 data are from Blackmore (2000) and 1997 data are from Li (2003). 

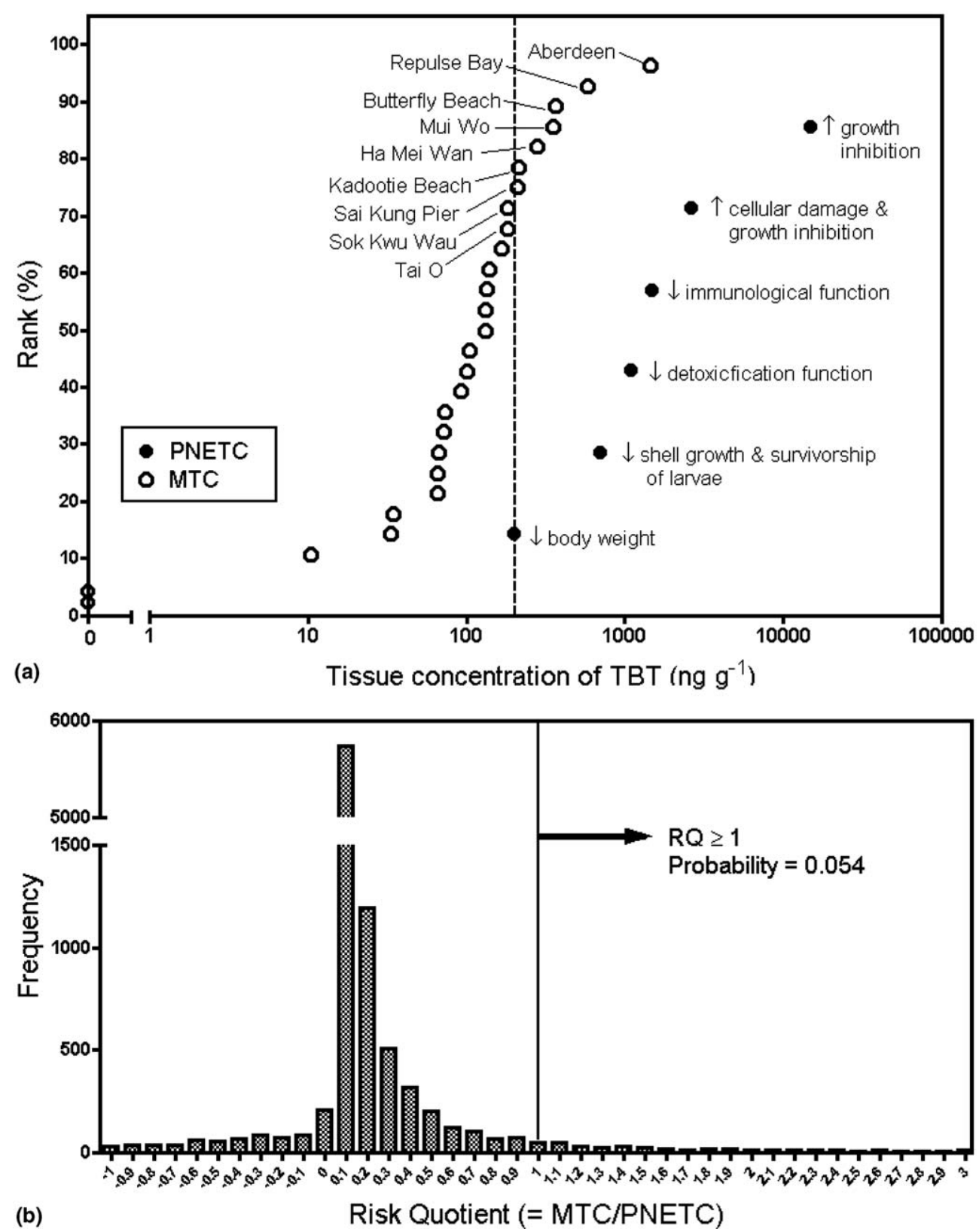

Fig. 5. Results of the probabilistic ecological risk assessment: (a) species sensitivity distribution to TBT contrasted from chronic toxicity data from literature (filled circle), i.e. distribution of PNETC and distribution of tissue TBT burden in Thais clavigera from various sites in Hong Kong (open circle), i.e. distribution of MTC and (b) the distribution of the computed risk quotient generated from Monte Carlo simulation.

TBT use restriction in 1992. From 1996 to 2004, both imposex indices remained at a similar level in areas within $10 \mathrm{~km}$ from the sites with high marine traffic or adjacent to large harbours/ports (Fig. 4). In contrast, there was a considerable reduction of RPSI between 1997 and 2004 at the areas $10 \mathrm{~km}$ or more away from the major shipping activities (Fig. 4). This was probably due to the implementation of restriction of TBT use on smaller vessels. In terms of percentage of sterilization (Appendix 3), it was noticed that there was some improvement at Sai Kung Pier, UST, and Chung Hum Kok sites where the marine traffic is dominated with small vessels. But the percentage of sterilization remained high at Deep Water Bay, Kadoorie Beach, Sok Kwu Wan and Aberdeen (Appendix 3).

\subsection{Risk assessment}

Studies on chronic toxicity of TBT on gastropod and bivalve molluscs were limited (Appendix 4). At low aqueous TBT levels $1-2 \mathrm{ng}^{-1}$, female neogastropods can develop imposex. The corresponding tissue concentration 
for imposex induction in $T$. clavigera was estimated to be about $33 \mathrm{ng}$ TBTCl g ${ }^{-1}$ dry wt (Appendix 4; Horiguchi et al., 1994). As low levels of imposex might not cause detrimental effect on individual lifetime fitness and population sustainability, such PNETCs were excluded from the construction of species sensitivity distribution (SSD). The final SSD included six PNETC values, covering endpoints such as inhibition of growth, reproduction and immunological suppression (Fig. 5a; Appendix 4). Based on the probabilistic risk assessment, $5.4 \%$ of all populations of $T$. clavigera are at risk (i.e. likely to suffer at least reduction in body weight) due to exposure to TBT (Fig. 5b). Based on the overlap of the MTC and PNETC distributions (Fig. 5a), seriously impacted areas included Aberdeen, Repulse Bay, Butterfly Beach, Mui Wo and Ha Mei Wan.

\section{Discussion}

There were great spatial variations in organotin (OT) contamination levels in Hong Kong waters, as shown by the tissue OT concentrations in the neogastropods. These large variations were strongly associated with marine traffic and shipping activities (Fig. 4). High OT body burden and imposex indices were observed in areas such as Aberdeen, Central Pier, and Tsim Sha Tsui where high frequencies of marine traffic or great number of large vessels are often encountered.

All female gastropods developed imposex characters from a total of 29 sampling sites for both species. Similar results were also obtained in past studies since 1990, $100 \%$ imposex rate was observed in T. clavigera in all 11 sampling sites in 1990 (Mak, 1992), in 10 of the 11 sampling sites in 1996 (Blackmore, 2000) and 26 of the 28 sites in 1997 ( $\mathrm{Li}, 2003$ ). Sites with $<100 \%$ imposex rate in past studies were Wu Kwai Sha (1996), Ma Shi Chau (1997) (in close proximity to $\mathrm{Wu}$ Kwai Sha), and Clear Water Bay (1997). All these sites are relatively far away from major shipping activities.

In general, eastern to northeast waters of Hong Kong (site no. 1-14) are less influenced by TBT pollution, as reflected by lower RPSI and VDSI values. These sites are remote from the commercial shipping activities and channels, and are more open to the prevailing oceanic current. However, the effect of OT contamination from Yantian Port appeared to have become more apparent overtime. Considering the imposex indices of five sites, i.e. 1, 2, 3, 6 and 7 (Fig. 1), which form a line away from Yantian Port, RPSI drop from 1.59 to 0.06 and VDSI from 3.92 to 2.38 . Tissue TBT concentration also showed a similar trend, indicating the Yantian Port as a potential source of TBT contaminant. Site 7 (Kong Tau Pai), which is located farthest from the shipping activities in mid-south waters and far away from Yantian Port, exhibited the lowest RPSI and VDSI recorded in this study. Continuous development of port activities in Hong Kong and Yantian may be expected to increase the threat of OT pollution to Hong Kong waters, especially in the northeastern region.
There was a significant pattern of sex ratio with respect to the imposex indexes and tissue organotin concentration in T. clavigera (Fig. 3), represented by male-biased population in sites with severe organotin contamination. The TBT related sex ratio alternation has been reported in T. clavigera (Tan, 1997; Blackmore, 2000; Shim et al., 2000; Li, 2003) and other gastropods, such as N. lapillus (Bryan et al., 1986), T. biserialis (Ramasamy and Murugan, 2002), Ocinehrina aciculate (Oehlmann et al., 1996b). The affected population may suffer from reproductive failure and even local extinction (Gibbs and Bryan, 1996; Evans et al., 1996). This phenomenon has been suggested to be caused by selective mortality on female (Bryan et al., 1986; Tan, 1997; Nicholson and Evans, 1997) or sex change of female to male (Oehlmann et al., 1996b; Rilov et al., 2000). Functional sex change of gastropod induced by organotins, however, has not been directly demonstrated at any developmental stage. Juvenile Buccinum undatum exposed to TBT, just after hatching, showed a dosedependent proportion of the young developing male sexual characters (Mensink et al., 1996), but no follow up study has been reported to ascertain whether the functional sex ratio is altered. Gibbs et al. (1988) recorded suppression of oogenesis and production of sperm in female $N$. lapillus raised from hatched juveniles under the influence of TBT. The reproductive function of masculinization was not determined, and was believed to be hypothetical due to the absence of sterile female in the study population. Moreover, an anatomical study on imposex females of $T$. clavigera showed a lack of testis and fully developed prostate gland that could prevent functional sex change $(\mathrm{Yu}$ et al., 2004). The drifted sex ratio in the present study is probably associated with an unequal mortality rate between the sexes that may be operating at different life stages.

Tissue TBT concentrations ranged from $<0.05$ to $18.33 \mathrm{ng} \mathrm{Sn} \mathrm{g}^{-1} \mathrm{dw}$ for $T$. clavigera and $2.68-33.48 \mathrm{ng} \mathrm{Sn}$ $\mathrm{g}^{-1} \mathrm{dw}$ for T. luteostoma in the present study. Higher values have been obtained in other studies of conspecifics, body TBT burden of 43-74 $\mathrm{ng} \mathrm{Sn} \mathrm{g}^{-1} \mathrm{dw}$ has been recorded in $T$. clavigera around mariculture areas in Taiwan (Hung et al., 2001). TBT concentrations of 5-508 ng $\mathrm{Sn}^{-1} \mathrm{dw}$ had been recorded in T. clavigera along the Korean coast, with generally $>200 \mathrm{ng} \mathrm{Sn} \mathrm{g^{-1 }}$ in animals near harbours and shipyards (Shim et al., 2000). Horiguchi et al. (1994) examined imposex and organotin levels in $T$. clavigera in Japan, TBT levels, measured in $\mathrm{ng} \mathrm{g}^{-1}$ as chloride in wet weight, were up to $420\left(\approx 185.3 \mathrm{ng} \mathrm{Sn}^{-1}\right.$ wet weight). In spite of different ranges of measured TBT concentrations, the correlation between imposex level and tissue burden of TBT as well as shipping activities have commonly been observed in all these studies. Although there were insufficient data on imposex level and TBT tissue burden of $T$. luteostoma, the general patterns of imposex development and organotin accumulation revealed in the current study were similar to those of $T$. clavigera, suggesting their potential use as a good biomonitor. 
Restriction of TBT usage in 1992 seemed to have been somewhat effective in Hong Kong, as represented by a drop of RPSI from 1990 to 1996 in all areas and from 1996/1997 to 2004 in areas at $10 \mathrm{~km}$ or more away from major shipping activities. However, imposex levels did not show any further reduction from 1996/97 to 2004 in areas within $10 \mathrm{~km}$ of major shipping activities. A similar conclusion was reached in a comparable study conducted in Iceland using N. lapillus (Jörundsdóttir et al., 2005). Recovery or re-colonization of gastropod populations has been reported in different taxa and locations after the restriction of TBT-based antifoulant application (e.g. Evans et al., 1995; references cited in Jörundsdóttir et al., 2005); the problem persisted, however, in other cases (e.g. Oehlmann et al., 1998; Horiguchi, 2000; Santos et al., 2002; Gibson and Wilson, 2003). The persistence of organotin pollution showed that the contaminant has not been effectively, or only partially, suppressed by the existing regulation. In fact, many studies have reported that levels of organotin remained high near commercial ports even though significant decline occurred in the peripheral areas (Evans et al., 2001; Reitsema et al., 2003). The majority of the vessels utilizing Hong Kong waters were commercial vessels of over $25 \mathrm{~m}$ that were not regulated in their application of TBT-based antifoulant. Additionally, weak enforcement of regulation (Ko et al., 1995) and poor dock practice (Birchenough et al., 2002) in Hong Kong concomitantly amplify the problem of OT contamination.

To understand the suitability of using Thais spp. as bioindicators for assessing the possible change in the ambient organotin levels in the future, especially when the IMO Antifouling Convention becomes effective, the sensitivity of the species to temporal OT variation is important. $T$. clavigera has been shown to be sensitive to TBT (Horiguchi et al., 1994, 1995, 1997). Imposex was induced in adult female $T$. clavigera at an environmental concentration of approximately $1 \mathrm{ng}^{-1}$ of TBT in 85-day flow-through exposure experiments, and imposex was promoted 30 days post either TBT or TPT (triphenyltin) injection (Horiguchi et al., 1995, 1997). There was a good correlation between imposex level and TBT concentration for $T$. clavigera (Horiguchi et al., 1994; present study). However, as the development of imposex is an irreversible process (Gibbs et al., 1987), the degree of imposex in an animal can only reflect the elevation of OTs during its life span. The irreversible nature of imposex and the relative long life cycle of these gastropods may limit the responsiveness of the animal to a decrease of TBT level (Foale, 1993; Gibbs and Bryan, 1996). T. clavigera is a perennial species with a life span of 7 years or more and maturity is attained after about 2 years (Tong, 1986). On this basis, a rapid drop in aqueous TBT concentration may take more than 2 years to be reflected by the imposex status in the new cohorts.

It is believed that tissue TBT concentration is a reliable alternative for monitoring short-term change. The reaction (response) time of tissue concentration is shorter, half-life of TBT in mollusc tissue has been reported to be 22 days in T. clavigera (Horiguchi et al., 1995), 11-36 days in the clam, Venerupis decussata (Gomez-Ariza et al., 1999), 26 days in the bivalve Dreissena polymorpha (Van Slooten and Tarradellas, 1994), and about 2-3 months in the gastropod Nassarius reticulates (Sousa et al., 2005). An OT injection experiment showed that tissue TBT concentration of $T$. clavigera declined from 221.6 and $900.8 \mathrm{ng} \mathrm{g}^{-1}$ wet weight in day 2 of injection to 20.3 and $116.6 \mathrm{ng} \mathrm{g}^{-1}$ wet weight in 30 days, respectively (Horiguchi et al., 1997). Thus, half-life of TBT in mollusc tissue is relatively short, and tissue concentration may be useful in reflecting the recent changes in ambient OT levels.

Nowadays, many pollutant measurements, particularly those for lipophilic compounds, are carried out using sediment or biota samples rather than water samples, because of the large variations and tiresome procedures for seawater chemical analysis due to low water solubility of these chemicals (Leung and Lam, 2004). As a result, tissue burden data of these contaminants are often more available than those in other environmental media. There are a number of issues in regard to how these data can be used in ecological risk assessment (ERA). Can we directly apply these tissue burden data in ERA? What is the threshold tissue level of a particular substance? At present, the most commonly used method in ERA is based on two major parameters, namely predicted environmental concentrations (PECs) and predicted no effect concentrations (PNECs). The former is usually obtained by quantifying the concentrations of a particular pollutant in water or sediment samples which are randomly collected in the environment of interest. A PNEC of a substance is based on its toxic effects on single, individual-level endpoints (e.g., survival, fecundity, and growth; LCx, ECx or NOEC) and derived using either fixed application factor approach or one of the species sensitivity distribution (SSD) models (Wheeler et al., 2002). Subsequently, a statistical distribution of the risk quotient (RQ) can be computed as a ratio of PECs/PNECs using Monte Carlo simulation. If $\mathrm{RQ}>1$, the ecosystem is at risk. However, a number of problems have been identified when using this model. Most available toxicity data for ERA are derived from toxicity tests using seawater and, to a lesser extent, sediment as a test medium. The situation is that we often have PECs in terms of pollutant concentrations in biota whereas most PNECs are water-based. In the present study, an attempt has been made to utilize appropriate bioconcentration factors (BCFs) to estimate the tissue body burden of TBT in the gastropod and bivalve molluscs used in chronic or sub-chronic toxicity tests. In so doing, PEC and PNEC can be converted/standardized to MTC and PNETC for probabilistic ERA. The present study demonstrates that this approach is workable and can provide an effective solution to make use of body burden data in direct ERA.

In conclusion, imposex was recorded in all female $T$. clavigera and T. luteostoma from 29 sites in Hong Kong. RPSI and VDSI were significantly correlated with tissue 
organotin and TBT concentration. Imposex level and body burden organotin were highest in populations nearest to major shipping activities/facilities, and gradually decreased with distance away from these sources. A decline in imposex level was recorded after the enforcement of TBT regulation in 1992. Since then, there was some further reduction of RPSI in areas $10 \mathrm{~km}$ or more away from major shipping activities, but no apparent improvement in areas within $10 \mathrm{~km}$ of major shipping activities between 1996/97 and 2004. Yantian Port, a rapid development port facility in Mainland China since 1996, posed a new source of TBT contamination to the eastern waters of Hong Kong. The threat of TBT pollution has persisted over the last $7 / 8$ years and may be expected to increase with the further port development activities. The IMO convention of TBT-anti- fouling paint prohibition is considered necessary to reduce OT pollution in Hong Kong waters.

\section{Acknowledgements}

This study was supported by the Central Allocation Grant (8730020) awarded by the Research Grants Council and the Area of Excellence Scheme under the University Grants Committee of the Hong Kong Special Administration Region, China (Project No. AoE/P-04/2004). The authors also thank the two anonymous reviewers for their constructive comments on the manuscript, Dr. Gray Williams for helpful discussion and student helpers from the Department of Ecology \& Biodiversity for assistance in field sampling.

\section{Appendix 1}

Port vessel activity of Hong Kong in 1994, 1999 and 2004. Percentage change over the past 5 years are presented in parenthesis (Source: Marine Department of Hong Kong SAR, 2005).

\begin{tabular}{lrrr}
\hline Port vessel activity & \multicolumn{1}{c}{1994} & \multicolumn{1}{c}{1999} & \multicolumn{1}{c}{2004} \\
\hline Ocean Cargo Vessels & 34750 & $35140(+1.1 \%)$ & $32540(-7.4 \%)$ \\
Ocean Passenger Vessels & 2250 & $2430(+8.0 \%)$ & $3360(+38.3 \%)$ \\
River Cargo Vessels & 92050 & $115330(+25.3 \%)$ & $117540(+1.9 \%)$ \\
River Passenger Vessels & 63180 & $59930(-5.1 \%)$ & $71980(+20.1 \%)$ \\
Total & 192230 & $212840(+10.7 \%)$ & $225430(+5.9 \%)$ \\
\hline
\end{tabular}

\section{Appendix 2}

Results of Spearman's rank correlation between organotins (OT: total organotin; TBT: tributyltin; DBT: dibutyltin; MBT: monobutyltin) and imposex indexes (RPSI: relative penis size index; VDSI: vas deferens sequence index) and percentage of sterilized females for $T$. clavigera and T. luteostoma, respectively; n.s.: not significant.

\begin{tabular}{|c|c|c|c|c|c|}
\hline \multirow[t]{2}{*}{ Factor } & \multirow[t]{2}{*}{ Variance } & \multicolumn{2}{|c|}{ Thais clavigera } & \multicolumn{2}{|c|}{ Thais luteostoma } \\
\hline & & $r_{s}$ & $p$ & $r_{s}$ & $p$ \\
\hline \multirow[t]{3}{*}{ OT } & RPSI & 1 & $<0.001$ & 1 & $<0.001$ \\
\hline & VDSI & 1 & $<0.001$ & 1 & $<0.001$ \\
\hline & $\%$ Sterilized female & 0.421 & 0.029 & 0.906 & 0.005 \\
\hline \multirow[t]{3}{*}{ TBT } & RPSI & 0.664 & 0.001 & 0.937 & 0.007 \\
\hline & VDSI & 0.684 & $<0.001$ & 0.893 & 0.012 \\
\hline & $\%$ Sterilized female & 0.546 & 0.003 & 0.906 & 0.005 \\
\hline \multirow[t]{3}{*}{ DBT } & RPSI & 0.606 & $<0.001$ & n.s. & n.s. \\
\hline & VDSI & 0.742 & $<0.001$ & n.s. & n.s. \\
\hline & $\%$ Sterilized female & 0.485 & 0.010 & 0.915 & 0.004 \\
\hline \multirow[t]{3}{*}{ MBT } & RPSI & n.s. & n.s. & n.s. & n.s. \\
\hline & VDSI & n.s. & n.s. & n.s. & n.s. \\
\hline & $\%$ Sterilized female & n.s. & n.s. & n.s. & n.s. \\
\hline
\end{tabular}




\section{Appendix 3}

Site name, vas deferens sequence index (VDSI), relative penis size index (RPSI) and percentage of sterilized females of Thais clavigera at all locations. Data of 1990 are from Mak (1990), 1996 data are from Blackmore (2000) and 1997 data are from Li (2003).

\begin{tabular}{|c|c|c|c|c|c|c|c|c|c|c|c|c|}
\hline \multirow[t]{2}{*}{ No. } & \multirow[t]{2}{*}{ Site } & \multicolumn{4}{|l|}{ RPSI } & \multicolumn{3}{|c|}{ VDSI } & \multicolumn{4}{|c|}{$\%$ Sterilization } \\
\hline & & 1990 & 1996 & 1997 & 2004 & 1996 & 1997 & 2004 & 1990 & 1996 & 1997 & 2004 \\
\hline \multicolumn{13}{|c|}{ T. clavigera } \\
\hline 1 & Kat $\mathrm{O}$ & 5.7 & & & 1.6 & & & 3.92 & 0.0 & & & 0.0 \\
\hline 2 & Pak Sha Chau & & & & 0.4 & & & 3.57 & & & & 0.0 \\
\hline 3 & Chek Chau & & & & 0.6 & & & 3.50 & & & & 0.0 \\
\hline 4 & Wu Kwai Sha & & 0.1 & 0.8 & 0.2 & 2.00 & 2.89 & 2.67 & & 0.0 & 0.0 & 0.0 \\
\hline 5 & Heng On Estate & & & 6.0 & 0.8 & & 3.36 & 3.64 & & & 0.0 & 0.0 \\
\hline 6 & Wong Mau Chau & & & & 0.1 & & & 3.03 & & & & 0.0 \\
\hline 7 & Kong Tau Pai & & & & 0.1 & & & 2.38 & & & & 0.0 \\
\hline 8 & Sai Kung Pier & & & 45.3 & 34.4 & & 4.97 & 4.70 & & & 63.0 & 40.0 \\
\hline 9 & UST & & 15.0 & & 8.9 & 4.00 & & 4.17 & & 19.0 & & 11.1 \\
\hline 10 & Clear Water Bay & 47.3 & 0.6 & 0.4 & 0.5 & 2.00 & 3.08 & 3.04 & 0.0 & 0.0 & 0.0 & 0.0 \\
\hline 11 & Shek Mei Tao & & & & 0.1 & & & 3.22 & & & & 0.0 \\
\hline 12 & Tung Lung Island & & & 11.9 & 12.6 & & 3.81 & 4.00 & & & 0.0 & 0.0 \\
\hline 13 & Waglan Island & & & & 0.2 & & & 3.00 & & & & 0.0 \\
\hline 14 & Po Toi & & & 4.4 & 2.3 & & 3.48 & 3.52 & & & 0.0 & 0.0 \\
\hline 15 & Shek O & & & 9.8 & 29.7 & & 3.59 & 3.90 & & & 0.0 & 5.0 \\
\hline 16 & Turtle Cove & & & 2.6 & 0.4 & & 3.50 & 3.33 & & & 0.0 & 0.0 \\
\hline 17 & Chung Hum Kok & & & 26.9 & 9.0 & & 4.22 & 4.10 & & & 22.0 & 4.8 \\
\hline 18 & Repulse Bay & & & 20.9 & 11.8 & & 3.92 & 3.90 & & & 0.0 & 10.5 \\
\hline 19 & Deep Water Bay & & & 32.9 & 7.7 & & 4.25 & 4.35 & & & 25.0 & 29.4 \\
\hline 20 & Aberdeen & 97.3 & 41.3 & 45.8 & 64.2 & 6.00 & 5.09 & 5.00 & 85.7 & 92.0 & 67.0 & 83.3 \\
\hline 21 & Sok Kwu Wan & 71.4 & & 49.8 & 12.1 & & 5.13 & 5.36 & 81.3 & & 71.0 & 71.4 \\
\hline 22 & Ha Mei Wan & & & 9.2 & 1.9 & & 3.50 & 3.65 & & & 0.0 & 0.0 \\
\hline 23 & Mui Wo & 61.7 & & 32.0 & 3.0 & & 4.11 & 4.00 & 10.0 & & 11.0 & 0.0 \\
\hline 24 & Cheung sha & & 3.9 & & 1.3 & 3.00 & & 4.00 & & 0.0 & & 0.0 \\
\hline 25 & Tai O & 20.7 & 10.6 & 6.6 & 3.2 & 3.00 & 3.44 & 3.79 & 0.0 & 0.0 & 0.0 & 0.0 \\
\hline 26 & Butterfly Beach & & & & 15.6 & & & 4.11 & & & & 33.3 \\
\hline 27 & Kadoorie Beach & & 21.8 & 53.4 & 38.4 & 4.00 & 4.85 & 4.87 & & 21.0 & 64.0 & 53.3 \\
\hline
\end{tabular}

\section{Appendix 4}

Chronic and subchronic toxicity values of body burden tributyltin (ng $\mathrm{g}^{-1}$ dry weight; listed in an ascending order) for various molluscs. Bold values were used for constructing the species sensitivity distribution (see Fig. 5a).

\begin{tabular}{llllllll}
\hline Group & Species & $\begin{array}{l}\text { Chronic } \\
\text { value } \\
(\mathrm{ng} / \mathrm{l})\end{array}$ & $\begin{array}{l}\text { Exposure } \\
\text { duration } \\
\text { (days) }\end{array}$ & $\begin{array}{l}\text { Biocon- } \\
\text { centration } \\
\text { factor }(\mathrm{BCF})\end{array}$ & $\begin{array}{l}\text { Estimated } \\
\text { body burden } \\
\text { concentration }(\mathrm{ng} / \mathrm{g})\end{array}$ & $\begin{array}{l}\text { Type of } \\
\text { chronic } \\
\text { value }\end{array}$ & $\begin{array}{l}\text { End point of } \\
\text { toxicity }\end{array}$ \\
\hline Gastropod & $\begin{array}{l}\text { Littorina } \\
\text { littorea }\end{array}$ & 2 & Field study & $34600^{\mathrm{a}}$ & 69.2 & LOEC & $\begin{array}{l}\text { Female developed } \\
\text { intersex }\end{array}$
\end{tabular}


Appendix 4 (continued)

\begin{tabular}{|c|c|c|c|c|c|c|c|}
\hline Group & Species & $\begin{array}{l}\text { Chronic } \\
\text { value } \\
(\mathrm{ng} / \mathrm{l})\end{array}$ & $\begin{array}{l}\text { Exposure } \\
\text { duration } \\
\text { (days) }\end{array}$ & $\begin{array}{l}\text { Biocon- } \\
\text { centration } \\
\text { factor }(\mathrm{BCF})\end{array}$ & $\begin{array}{l}\text { Estimated } \\
\text { body burden } \\
\text { concentration } \\
(\mathrm{ng} / \mathrm{g})\end{array}$ & $\begin{array}{l}\text { Type of } \\
\text { chronic } \\
\text { value }\end{array}$ & $\begin{array}{l}\text { End point of } \\
\text { toxicity }\end{array}$ \\
\hline \multirow[t]{3}{*}{ Gastropod } & \multirow[t]{3}{*}{$\begin{array}{l}\text { Nucella } \\
\text { lapillus }\end{array}$} & 1 & Field study & $100000^{\mathrm{c}}$ & 100 & LOEC & $\begin{array}{l}\text { Females lost weight } \\
\text { and developed imposex }\end{array}$ \\
\hline & & \multirow[t]{2}{*}{2} & \multirow[t]{2}{*}{8} & \multirow[t]{2}{*}{$100000^{\mathrm{c}}$} & 200 & LOEC & \multirow[t]{2}{*}{$\begin{array}{l}\text { Females lost weight } \\
\text { and developed imposex }\end{array}$} \\
\hline & & & & & 141 & Geomean & \\
\hline Gastropod & $\begin{array}{l}\text { Thais } \\
\text { clavigera }\end{array}$ & N.A. & Field study & N.A. & $\begin{array}{l}\text { 10-20 ng } \\
\text { TBTCl/g } \\
\text { wet tissue }^{\mathrm{u}}\end{array}$ & LOEC & $\begin{array}{l}\text { Females developed } \\
\text { imposex }^{\mathrm{f}}\end{array}$ \\
\hline Gastropod & $\begin{array}{l}\text { Thais } \\
\text { clavigera }\end{array}$ & ca. 1 & 85 & $\begin{array}{l}5000- \\
10000^{\mathrm{g}}\end{array}$ & $\begin{array}{l}\text { ca. } 20 \mathrm{ng} \\
\text { TBTCl/g } \\
\text { wet tissue }^{\mathrm{u}}\end{array}$ & LOEC & $\begin{array}{l}\text { Females developed } \\
\text { imposex } \mathrm{g}\end{array}$ \\
\hline Gastropod & $\begin{array}{l}\text { Hinia } \\
\text { incrassata }\end{array}$ & 1.5 & Field study & $122000^{\mathrm{h}}$ & 183 & LOEC & $\begin{array}{l}\text { Development of } \\
\text { imposex }^{\mathrm{h}}\end{array}$ \\
\hline Bivalve & $\begin{array}{l}\text { Scrobicularia } \\
\text { plana }\end{array}$ & 14 & 30 & $50000^{\mathrm{i}}$ & 700 & LOEC & $\begin{array}{l}\text { Reduce larval } \\
\text { shall growth and } \\
\text { survivorship }\end{array}$ \\
\hline Bivalve & $\begin{array}{l}\text { Ruditapes } \\
\text { decussata }\end{array}$ & 90 & 7 & $12000^{\mathrm{k}}$ & 1080 & LOEC & $\begin{array}{l}\text { Elevation in the } \\
\text { NADPH cytochrome } \\
(\text { P450) reductases and } \\
\text { decrease in NADH } \\
\text { cytochrome } b_{5} \\
\text { reductases }\end{array}$ \\
\hline Bivalve & $\begin{array}{l}\text { Crassostrea } \\
\text { virginica }\end{array}$ & 30 & 63 & $49000^{\mathrm{m}}$ & 1470 & LOEC & $\begin{array}{l}\text { Decrease resistance } \\
\text { against bacterial } \\
\text { challenge }^{\mathrm{n}}\end{array}$ \\
\hline \multirow[t]{3}{*}{ Bivalve } & \multirow[t]{3}{*}{$\begin{array}{l}\text { Mytilus } \\
\text { edulis }\end{array}$} & 5 & 32 & $400000^{\circ}$ & 2000 & NOEC & $\begin{array}{l}\text { Activity of hemocyte } \\
\text { and membrane injury }\end{array}$ \\
\hline & & 5.4 & 15 & $400000^{\circ}$ & 2160 & $\mathrm{EC} 10$ & Growth rate reduction ${ }^{\mathrm{q}}$ \\
\hline & & 10 & 60 & $400000^{\circ}$ & 4000 & LOEC & Reduced shell growth ${ }^{\mathrm{r}}$ \\
\hline Bivalve & $\begin{array}{l}\text { Crassostrea } \\
\text { gigas }\end{array}$ & 48 & Field study & $310000^{\mathrm{s}}$ & $\begin{array}{r}2585 \\
14880\end{array}$ & $\begin{array}{l}\text { Geomean } \\
\text { LOEC }\end{array}$ & Growth inhibition $^{t}$ \\
\hline
\end{tabular}

a Kure and Depledge (1994).

b Oehlmann (2004).

${ }^{c}$ Bryan et al. (1993).

d Gibbs et al. (1987).

e Davies et al. (1997).

${ }^{\mathrm{f}}$ Horiguchi et al. (1994).

g Horiguchi et al. (1995).

h Oehlmann et al. (1998).

${ }^{i}$ Bryan and Gibbs (1991).

${ }_{\mathrm{k}}^{\mathrm{j}}$ Ruiz et al. (2005).

${ }^{k}$ Morcillo and Porte (2000).

${ }^{1}$ Sole (2000).

${ }^{\mathrm{m}}$ Roberts et al. (1987).

${ }^{\mathrm{n}}$ Fisher et al. (1999).

o Salazar and Salazar (1991).

p St-Jean et al. (2002).

${ }^{\mathrm{q}}$ Stenalt et al. (1998).

${ }^{\mathrm{r}}$ Huang and Yong (1995).

s Roberts et al. (1987).

${ }^{\mathrm{t}}$ Batley et al. (1989).

" Supposing that moisture content of the whole soft tissue of Thais clavigera is $70 \%$, the values can be translated into approximately $33-67$ and $67 \mathrm{ng} \mathrm{TBTCl} \mathrm{g}{ }^{-1}$ dry tissue, respectively. 


\section{References}

Alzieu, C., 1996. Biological effects of tributyltin in marine organisms. In: de Mora, S.J. (Ed.), Tributyltin: Case Study of an Environmental Contaminant, Cambridge Environmental Chemistry Series, vol. 8. Cambridge University Press, Cambridge, pp. 167-211.

Batley, G.E., Fuhua, C., Brockbank, C.I., Flegg, K.J., 1989. Accumulation of tributyltin by the Sydney rock oyster, Saccostrea commercialis. Aus. J. Mar. Freshwater Res. 40, 49-54.

Birchenough, A.C., Barnes, N., Evans, S.M., Hinz, H., Kroenke, I., Moss, C., Kronke, I., 2002. A review and assessment of tributyltin contamination in the North Sea, based on surveys of butyltin tissue burdens and imposex/intersex in four species of neogastropods. Mar. Pollut. Bull. 44, 534-543.

Blaber, S.J.M., 1970. The occurrence of a penis-like outgrowth behind the right tentacle in spent females of Nucella lapillus (L.). Proc. Malacol. Soc. London 39, 231-233.

Blackmore, G., 2000. Imposex in Thais clavigera (Neogastropoda) as an indicator of TBT (tributyltin) bioavailability in coastal waters of Hong Kong. J. Mollus. Stud. 66, 1-8.

Bennett, R.F., 1996. Industrial manufacture and applications of tributyltin coumpounds. In: de Mora, S.J. (Ed.), Tributyltin: Case Study of an Environmental Contaminant, Cambridge Environmental Chemistry Series, vol. 8. Cambridges University Press, Cambridge, pp. 2161.

Bettin, C., Oehlmann, J., Stroben, E., 1996. TBT-induced imposex in marine neogastropods is mediated by an increasing androgen level. Helgol. Meeresunters. 50, 299-317.

Bryan, G.W., Bright, D.A., Hummerstone, L.G., Burt, G.R., 1993. Uptake, tissue distribution and metabolism of super(14)C-labelled tributyltin (TBT) in the dog-whelk, Nucella lapillus. J. Mar. Biol. Assoc. UK 73, 889-912.

Bryan, G.W., Gibbs, P.E., 1991. Impact of low concentrations of tributyltin (TBT) on marine organisms: a review. In: Newman, M.C., McIntosh, A.W. (Eds.), Metal Ecotoxicology: Concepts and Application. Lewis Publishers, Boston, pp. 323-361.

Bryan, G.W., Gibbs, P.E., Burt, G.R., Hummerstone, L.G., 1987. The effects of tributyltin (TBT) accumulation on adult dog-whelks, Nucella lapillus - long-term field and laboratory experiments. J. Mar. Biol. Assoc. UK 67, 525-544.

Bryan, G.W., Gibbs, P.E., Hummerstone, L.G., Burt, G.R., 1986. The decline of the gastropod Nucella lapillus around south-west England: evidence for the effect of tributyltin from antifouling paints. J. Mar. Biol. Assoc. UK 66, 611-640.

Chiavarini, S., Massanisso, R., Nicolai, P., Nobili, C., Morabito, R., 2003. Butyltins concentration levels and imposex occurrence in snails from the Sicilian coasts (Italy). Chemosphere 50, 311-319.

Davies, I.M., Harding, M.J.C., Bailey, S.K., Shanks, A.M., Lange, R., 1997. Sublethal effects of tributyltin oxide on the dogwhelk Nucella lapillus. Mar. Ecol. Prog. Ser. 158, 191-204.

de More, S.J., 1996. The tributyltin debate: ocean transportation versus seafood harvesting. In: de Mora, S.J. (Ed.), Tributyltin: Case Study of an Environmental Contaminant, Cambridge Environmental Chemistry, vol. 8. Cambridge University Press, Cambridge, pp. 1-20.

Evans, S.M., Leksono, T., Mckinnell, P.D., 1995. Tributyltin pollution: a diminishing problem following legislation limiting the use of TBTbased anti-fouling paints. Mar. Pollut. Bull. 30, 14-21.

Evans, S.M., Evans, P.M., Leksono, T., 1996. Widespread recovery of dogwhelks, Nucella lapillus (L.), from tributyltin contamination in the North Sea with Clyde Sea. Mar. Pollut. Bull. 32, 263-269.

Evans, S.M., Barnes, N., Birchenough, A.C., Brancato, M.S., Hardman, E., 2001. Tributyltin contamination in two estuaries and adjacent ocean coast: Puget Sound, Washington and Narragansett Bay, Rhode Island (USA). Invert. Reprod. Develop. 39, 221-229.

Féral, C., LeGall, S., 1983. The inflouence of a pollutant factor (TBT) on the neurosecretory mechanism responsible for the occurrence of a penis in the females of Ocenebra erinacea. In: Lever, J., Boer, H.H.
(Eds.), Molluscan Neuro-Endocrinology. North Holland Publishing, Amsterdam, pp. 173-175.

Fisher, W.S., Oliver, L.M., Walker, W.W., Manning, C.S., Lytle, T.F., 1999. Decreased resistance of eastern oysters (Crassostrea virginica) to a protozoan pathogen (Perkinsus marinus) after sublethal exposure to tributyltin oxide. Mar. Environ. Res. 47, 185-201.

Foale, S., 1993. An evaluation of the potential of gastropod imposex as a bioindicator of tributyltin pollution in Port Phillip Bay, Victoria. Mar. Pollut. Bull. 26, 546-552.

Gibbs, P.E., Bryan, G.W., 1986. Reproductive failure in populations of the dog-whelk, Nucella lapillus, caused by imposex induced by tributyltin from antifouling paints. J. Mar. Biol. Assoc. UK 66, 767777.

Gibbs, P.E., Bryan, G.W., 1996. TBT-induced imposex in neogastropod snails: masculinization to mass extinction. In: de Mora, S.J. (Ed.), Tributyltin: Case Study of an Environmental Contaminant. Cambridge University Press, Cambridge, pp. 212-236.

Gibbs, P.E., Bryan, G.W., Pascoe, P.L., Burt, G.R., 1987. The use of dogwhelk, Nucella lapillus, as an indicator of tributyltin (TBT) contamination. J. Mar. Biol. Assoc. UK 67, 507-523.

Gibbs, P.E., Pascoe, P.L., Burt, G.R., 1988. Sex change in the female dogwhelk, Nucella lapillus, induced by tributyltin form antifouling paints. J. Mar. Biol. Assoc. UK 68, 715-731.

Gibson, C.P., Wilson, S.P., 2003. Imposex still evident in eastern Australia 10 years after tributyltin restrictions. Mar. Environ. Res. 55, 101-112.

Gomez-Ariza, J.L., Morales, E., Giraldez, I., 1999. Uptake and elimination of tributyltin in clams, Venerupis decussata. Mar. Environ. Res. 47, 399-413.

Horiguchi, T., 2000. Molluscs. In: Kawai, S., Koyama, J. (Eds.), Problems of Endocrine Disruptors in Fisheries Environment. Koseisha-Koseikaku, Tokyo, pp. 54-72 (in Japanese).

Horiguchi, T., Shiraishi, H., Schimuzu, M., Morita, M., 1994. Imposex and organotin compounds in Thais clavigera and T. bronni in Japan. J. Mar. Biol. Assoc. UK 74, 651-669.

Horiguchi, T., Shiraishi, H., Shimizu, M., Yamazaki, S., Morita, M., 1995. Imposex in Japanese gastropods (Neogastropoda and Mesogastropoda): effects of tributyltin and triphenyltin from antifouling paints. Mar. Pollut. Bull. 31, 402-405.

Horiguchi, T., Shiraishi, H., Schimisu, M., Morita, M., 1997. Effects of triphenyltin chloride and five other organotin compounds on the development of imposex in the rock shell, Thais clavigera. Environ. Pollut. 95, 85-91.

Huang, G.L., Yong, W., 1995. Effects of tributyltin chloride on marine bivalve mussels. Water Res. 29, 1877-1884.

Hung, T.C., Hsu, W.K., Mang, P.J., Chuang, A., 2001. Organotins and imposex in the rock shell, Thais clavigera, from oyster mariculture areas in Taiwan. Environ. Pollut. 112, 145-152.

IMO, 2005. International Convention on the Control of Harmful Antifouling Systems on Ships. Available from: <http://www.imo.org/ home.asp?topic id=161>. Visited on 15 July 2005.

Jörundsdóttir, K., Svavarsson, J., Leung, K.M.Y., 2005. Imposex levels in the dogwhelk Nucella lapillus (L.)-continuing improvement at high latitudes. Mar. Pollut. Bull. 51, 744-749.

Kan-Atireklap, S., Tanabe, S., Sanguansin, J., 1997. Contamination by butyltin compounds and organochlorine residues in green mussel (Perna viridis L.) from Thailand coastal waters. Environ. Pollut. 97, 79-89.

Ko, M.M.C., Bradley, G.C., Neller, A.H., Broom, M.J., 1995. Tributyltin contamination of marine sediments of Hong Kong. Mar. Pollut. Bull. $31,249-253$.

Kure, L.K., Depledge, M.H., 1994. Accumulation of organotin in Littorina littorea and Mya arenaria from Danish coastal waters. Environ. Poll. 84, 149-157.

Lau, M.M., 1991. Tributyltin antifoulings: a threat to the Hong Kong marine environment. Arch. Environ. Contam. Toxicol. 20, 299-304.

Leung, K.M.Y., Lam, P.K.S., 2004. Marine ecological risk assessments are not straightforward! SETAC Globe 5, 35-36. 
Leung, K.M.Y., Wheeler, J.R., Morritt, D., Crane, M., 2001. Endocrine disruption in fishes and invertebrates: issues for saltwater ecological risk assessment. In: Newman, M.C., Roberts, Jr., M.H., Hale, R.C. (Eds.), Coastal and Estuarine Risk Assessment. Lewis Publishers, Boca Raton, pp. 189-216.

Li, Z., 2003. The incidence of imposex in intertidal gastropods from Hong Kong. In: Shin, P.K.S. (Ed.), Turning the Tides, a Festschrift in Honour of Professor Brian Morton. The Marine Biological Association of Hong Kong, Hong Kong, pp. 227-254.

Mak, Y.M., 1992. The effects of TBT on dogwhelk population around Hong Kong. Environmental Science Project Report, The University of Hong Kong, pp. 65.

Marine Department of Hong Kong SAR, 2005. Port of Hong Kong in Figures. 2005 Edition.

Matthiessen, P., Gibbs, P.E., 1998. Critical appraisal of the evidence for tributyltin-mediated endocrine disruption in molluscs. Environ. Toxicol. Chem. 17, 37-43.

Matthiessen, P., Reynoldson, T., Billinghurst, Z., Brassard, D.W., Cameron, P., Chandler, G.T., Davis, I.M., Horiguchi, T., Mount, D.R., Oehlmann, J., Pottinger, T.G., Sibley, P.K., Thompsom, H.M., Vethaak, A.D., 1999. In: de Fur, P.L., Crane, M., Ingersoll, C., Tattersfield, L. (Eds.), Endocrine Disruption in Invertebrates: Endocrinology Testing and Assessment. SETAC Press, Pensacola, FL, pp. 199-270.

Mensink, B.P., Everaarts, J.M., Kralt, H., Ten Hallers-Tjabbes, C.C., Boon, J.P., 1996. Tributyltin exposure in early life stages induces the development of male sexual characteristics in the common whelk, Buccinum undatum. Mar. Environ. Res. 42, 151-154.

Morcillo, Y., Porte, C., 2000. Evidence of endocrine disruption in clams Ruditapes decussata transplanted to a tributyltin-polluted environment. Environ. Pollut. 107, 47-52.

Nishikawa, J., Mamiya, S., Kanayama, T., Nishikawa, T., Shiraishi, F., Horiguchi, T., 2004. Involvement of the retinoid $\mathrm{X}$ receptor in the development of imposex caused by organotins in gastropods. Environ. Sci. Tech. 38, 6271-6276.

Nicholson, G.J., Evans, S.M., 1997. Anthropogenic impacts on the stocks of the common whelk Buccinum undatum (L.). Mar. Environ. Res. 44, $305-314$.

Oberdörster, E., McClellan-Green, P., 2000. The neuropeptide APGWamide induces imposex in the mud snail Ilyanassa obsoleta. Peptides 21, $1323-1330$.

Oberdörster, E., McClellan-Green, P., 2002. Mechanism of imposex induction in mud snail, Ilyanassa obsoleta: TBT as a neurotoxin and aromatase inhibitor. Mar. Environ. Res. 54, 715-718.

Oehlmann, J., 2004. Biological effects of contaminants use of intersex in the periwinkle (Littorina littorea) as a biomarker of tributyltin pollution. ICES Tech. Mar. Environ. Sci. 37, 22.

Oehlmann, J., Stroben, E., Schulte-Oehlmann, U., Bauer, B., Fioroni, P., Markert, B., 1996a. Tributyltin biomonitoring using prosobranchs as sentinel organisms. Fresenius. J. Anal. Chem. 354, 540-545.

Oehlmann, J., Fioroni, P., Stroben, E., Markert, B., 1996b. Tributyltin (TBT) effects on Ocinebrina aciculate (Gastropoda: Muricidae): imposex development, sterilization, sex change and population decline. Sci. Tot. Environ. 188, 205-223.

Oehlmann, J., Stroben, E., Schulte-Oehlmann, U., Bauer, B., 1998. Imposex development in response to TBT pollution in Hinia incrassata (Strom, 1768) (Prosobranchia, Stenoglossa). Aquat. Toxicol. 43, 239260.

Ramasamy, M.S., Murugan, A., 2002. Imposex in muricid gastropod Thais biserialis (Mollusca: Neogastropoda: Muricidae) from Tuticorin Harbour, southeast coast of India. Indian J. Mar. Sci. 31, 243-245.

Reitsema, T.J., Field, S., Spickett, J.T., 2003. Surveying imposex in the coastal waters of Perth, Western Australia, to monitor trends in TBT contamination. Austral. J. Ecotoxicol. 9, 87-92.

Rilov, G., Gasith, A., Evans, S.M., Benayahu, Y., 2000. Unregulated use of TBT-based antifouling paints in Israel (eastern Mediterranean): high contamination and imposex levels in two species of marine gastropods. Mar. Ecol. Prog. Ser. 192, 229-238.
Roberts, M.H., Bender, M.E., DeLisle, P.F., 1987. Report (Project 9) for the Virginia State Water Control Board, Richmond, VA.

Ronis, M.J.J., Mason, A.Z., 1996. The metabolism of testosterone by the periwinkle ( Littorina littorea) in vitro and in vivo: effects of tributyltin. Mar. Environ. Res. 42, 161-166.

Ruiz, J.M., Barreiro, R., Gonzalez, J.J., 2005. Biomonitoring organotin pollution with gastropods and mussels. Mar. Ecol. Prog. Ser. 287, 169176.

Salazar, M.H., Salazar, S.M., 1991. Assessing site-specific effects of TBT contamination with mussel growth rates. Mar. Pollut. Bull. 28, 621628.

Santos, M.M., Ten Hallers-Tjabbes, C.C., Santos, A.M., Vieira, N., 2002. Imposex in Nucella lapillus, a bioindicator for TBT contamination: resurvey along the Portuguese coast to monitor the effectiveness of EU regulation. J. Sea Res. 48, 217-223.

Santos, M.M., Castro, L.F., Vieira, M.N., Michael, J., Morabito, R., Massanisso, P., Reis-Henriques, M.A., 2005. New insights into the mechanism of imposex induction in the dogwhelk Nucella lapillus. Comp. Biochem. Physiol. C - Toxicol. Pharmacol. 141, 101109.

Shim, W.J., Kahng, S.H., Hong, S.H., Kim, N.S., Kim, S.K., Shim, J.H., 2000. Imposex in the rock shell, Thais clavigera, as evidence of organotin contamination in the marine environment of Korea. Mar. Envrion. Res. 49, 435-451.

Smith, B.S., 1971. Sexuality in the American mud-snail, Nassarius obsoletus Say. Proc. Malacol. Soc. London 39, 377-378.

Smith, B.S., 1981a. Male characteristics on female mud snails caused by antifouling bottom paints. J. Appl. Toxicol. 1, 22-25.

Smith, B.S., 1981b. Tributyltin compounds induce male characteristics on female mud snail Nassarius obsoletus =Ilyanassa obsolete. J. Appl. Toxicol. 1, 141-144.

Sole, M., 2000. Effects of tributyltin on the MFO system of the clam Ruditapes decussata: a laboratory and field approach. Comp. Biochem. Physiol. C 125, 93-101.

Sousa, A., Mendo, S., Barroso, C., 2005. Imposex and organotin contamination in Nassarius reticulates (L.) along the Portuguese coast. Appl. Organometal. Chem. 19, 315-323.

Spooner, N., Gibbs, P.E., Bryan, G.W., Goad, L.J., 1991. The effect of tributyltin upon steroid titres in the female dogwhelk, Nucella lapillus, and the development of imposex. Mar. Environ. Res. 32, 37-49.

Stenalt, E., Johansen, B., Lillienskjold, S.V., Hansen, B.W., 1998. Mesocosm study of Mytilus edulis larvae and postlarvae, including the settlement phase, exposed to a gradient of tributyltin. Ecotoxicol. Environ. Safe. 40, 212-225.

St-Jean, S.D., Pelletier, E., Courtenay, S.C., 2002. Hemocyte functions and bacterial clearance affected in vivo by TBT and DBT in the blue mussel Mytilus edulis. Mar. Ecol. Prog. Ser. 236, 163-178.

Sudaryanto, A., Takahashi, S., Monirith, I., Ismail, A., Muchtar, M., Zheng, J., Richardson, B.J., Subramanian, A., Prudente, M., Hue, N.D., Tanabe, S., 2002. Asia-Pacific mussel watch: monitoring of butyltin contamination in coastal waters of Asian developing countries. Environ. Toxicol. Chem. 21, 2119-2130.

Szpunar, J., Schmitt, V.O., Lobinski, R., 1996. Rapid speciation of butyltin compounds in sediments and biomaterials by GC-AEDm, after microwave-assisted leaching-digestion. J. Anal. Atom. Spectrom. 11, 193-199.

Tan, K.S., 1997. Imposex in three species of Thais from Singapore, with additional observations on T. clavigera (Kuester) from Japan. Mar. Pollut. Bull. 34, 577-581.

Tong, K.Y., 1986. The population dynamics and feeding ecology of Thais clavigera (Küster) and Morula musiva (Küster) (Mollusca: Gastropoda: Muricidae) in Hong Kong. M.Phil. Thesis, The University of Hong Kong.

Tong, K.Y., 1988. The reproductive biology of Thais clavigera and Morula musive (Gastropoda: Muricidae) in Hong Kong. Asian Mar. Biol. 5, $65-75$.

Van Slooten, K.B., Tarradellas, J., 1994. Accumulation, depuration and growth effects of tributyltin in the freshwater bivalve Dreissena 
polymorpha under field conditions. Environ. Toxicol. Chem. 13, 755762.

Wheeler, J.R., Grist, E.P.M., Leung, K.M.Y., Morritt, D., Crane, M., 2002. Species sensitivity distribution: Data and model choice. Mar. Pollut. Bull. 45, 192-202.
Yu, X., Huang, C., Zhu, S., Shen, J., Dong, Q., 2004. Anatomical and histological studies on imposex of Thais clavigera. Haiyang yu Huzhao 35, 149-155 (in Chinese). 